
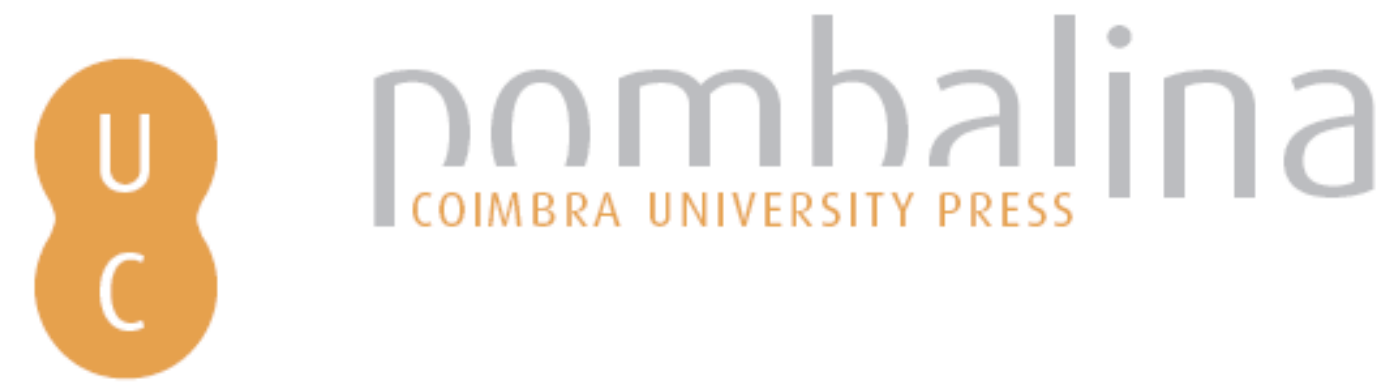

\title{
Maria Pia de Sabóia (1847-1911), rainha de Portugal: um pilar da monarquia portuguesa e das relações Portugal-Itália
}

\author{
Autor(es): Lopes, Maria Antónia
}

Publicado por: Imprensa da Universidade de Coimbra

URL

persistente: URI:http://hdl.handle.net/10316.2/32355

DOI: $\quad$ DOI:http://dx.doi.org/10.14195/978-989-26-0604-0_7

Accessed : $\quad$ 26-Apr-2023 00:11:19

A navegação consulta e descarregamento dos títulos inseridos nas Bibliotecas Digitais UC Digitalis, UC Pombalina e UC Impactum, pressupõem a aceitação plena e sem reservas dos Termos e Condições de Uso destas Bibliotecas Digitais, disponíveis em https://digitalis.uc.pt/pt-pt/termos.

Conforme exposto nos referidos Termos e Condições de Uso, o descarregamento de títulos de acesso restrito requer uma licença válida de autorização devendo o utilizador aceder ao(s) documento(s) a partir de um endereço de IP da instituição detentora da supramencionada licença.

Ao utilizador é apenas permitido o descarregamento para uso pessoal, pelo que o emprego do(s) título(s) descarregado(s) para outro fim, designadamente comercial, carece de autorização do respetivo autor ou editor da obra.

Na medida em que todas as obras da UC Digitalis se encontram protegidas pelo Código do Direito de Autor e Direitos Conexos e demais legislação aplicável, toda a cópia, parcial ou total, deste documento, nos casos em que é legalmente admitida, deverá conter ou fazer-se acompanhar por este aviso.

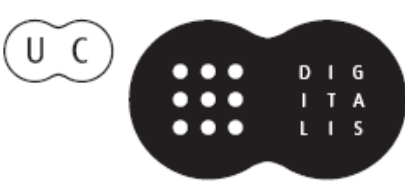




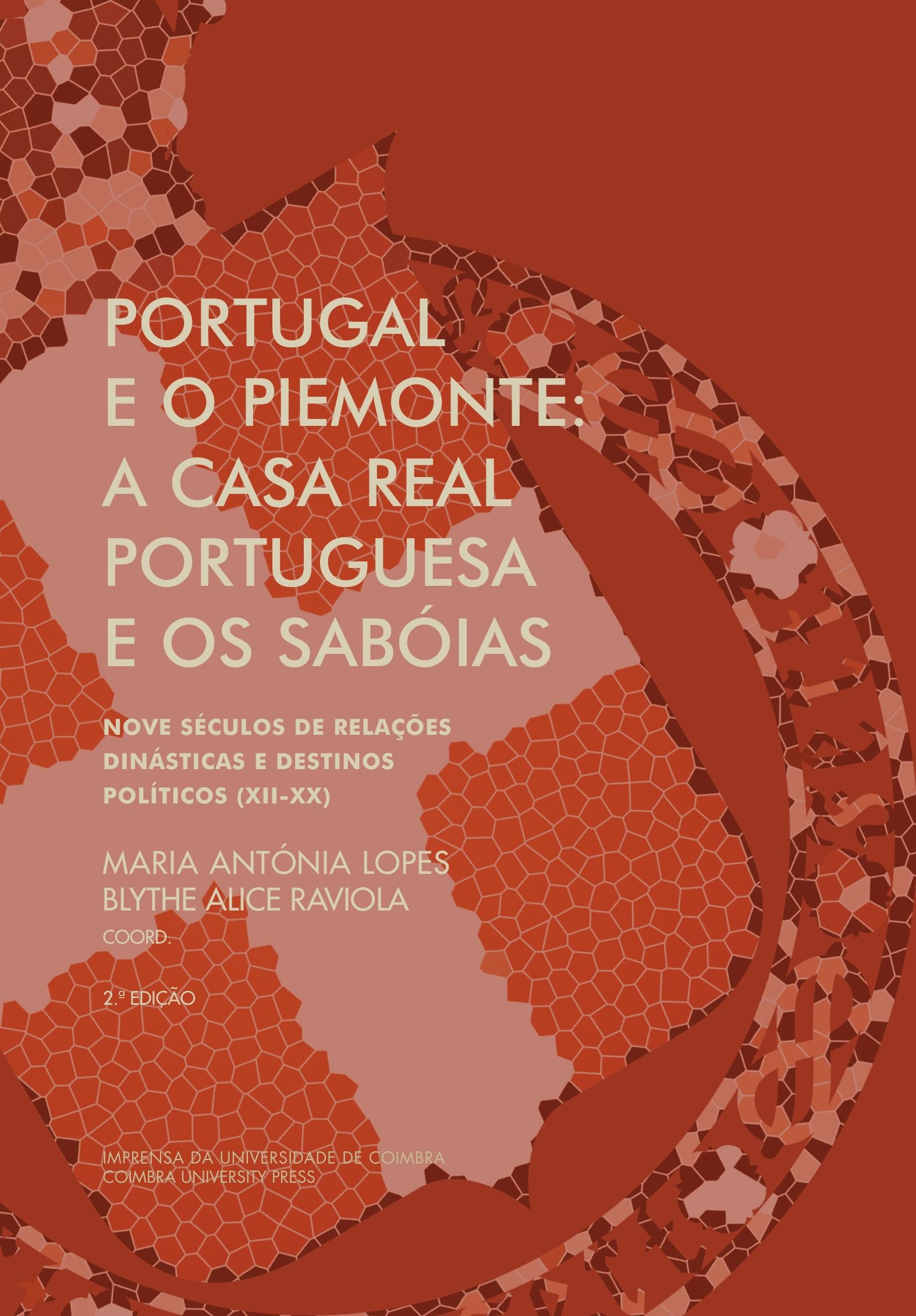


Maria Antónia Lopes

Universidade de Coimbra

\section{MARIA PIA DE SABÓIA (1847-1911), RAINHA DE PORTUGAL: UM PILAR DA MONARQUIA PORTUGUESA E dAS RELAÇÕes PORTUGAL-ITÁlia*}

\section{Rainha Maria Pia: memória e história}

A actual opinião pública portuguesa pouco sabe sobre Maria Pia de Sabóia. Contudo, viveu em Portugal desde 1862 a 1910 e foi, entre as rainhas do século XIX, a mais amada, a que mais tempo reinou e a que mais contribuiu para a boa imagem da família reinante. Até os seus críticos mais cruéis admitiam em 1910 - quando a República foi implantada - que era o único membro da família real que deixava saudades. No seu país de origem, a Itália, Maria Pia foi esquecida. Os estudos sobre os Sabóias do século XIX ignoram-na quase totalmente.

Os monárquicos portugueses que enaltecem a família real centram-se, quanto às figuras femininas, em D. Amélia, romantizada por ter sido a última rainha e pela sucessão de tragédias que sofreu, deixando D. Maria Pia na sombra, embora esta tenha vivido também parte desses dramas. Para traçar o panegírico e ressaltar as qualidades de D. Amélia de Orleães, os seus biógrafos franceses (que não são historiadores) não se coibiram em denegrir a sogra, com quem fizeram o confronto. Os actuais historiadores portugueses, questionando-se pouco ou nada sobre a personalidade

\footnotetext{
* O texto que se apresenta tem como base LOPES, M.A., 2011. Aqui salientar-se-á o papel político da rainha, tanto em Portugal como nas relações diplomáticas com Itália. Todas as informações e interpretações deste estudo podem ser vistas de forma mais desenvolvida na referida obra, assim como outros aspectos da biografia e personalidade de Maria Pia de Sabóia.
} 
de D. Maria Pia, têm repetido certos comentários da época e apreciações posteriores, mas é óbvio o desinteresse ou condescendência que sentem por alguém que consideram de insignificante importância. Por vezes parecem partilhar do estereótipo da mulher bela e elegante que forçosamente é fútil. Porque é assim que Maria Pia é apresentada: uma mulher frívola, temperamental, perdulária, pouco inteligente e instruída. E que por isso não era levada a sério nem pelos políticos e cortesãos, nem pelo marido, pelo filho mais velho ou pela sua família de origem. Afigura-se que, inconscientemente, certos autores assimilaram o que o século XIX pensava das capacidades cerebrais das mulheres. É também comum dizerem que teve episódios de loucura, ou, pelo menos, que era desequilibrada, e que enlouqueceu depois do regicídio. Na verdade, não encontrei na documentação primária o mais leve indício de desequilíbrio mental. Outra imagem forte desta rainha são os seus gastos excessivos, o que, ressalvando alguns exageros, corresponde à verdade. Por fim, uma questão recentemente tratada: Maria Pia teria tido um amante nos finais da década de 1880. E a situação terá sido de tal forma grave que o marido terá ponderado a separação e mesmo a sua própria abdicação do trono $^{1}$. Não me parece que, com as fontes disponíveis, se possam fazer tais afirmações ${ }^{2}$.

A imagem que em geral se veicula da rainha Maria Pia é quase antagónica daquela que a sua época traçou. Ao tempo, a maioria dos portugueses considerava-a caritativa, generosa, afável, mãe e educadora exemplar. Celebravam-lhe a elegância do porte, a coragem manifesta nos momentos decisivos, o sentido da majestade, o apoio sempre prestado ao marido, à dinastia e ao país, a simpatia e gentileza para com grandes e pequenos. Mas é verdade também que muitos aristocratas a viram sempre com maus olhos. Os católicos mais conservadores, associando-a ao pai, Vítor Manuel II de Itália, e vendo-a arredia das manifestações religiosas públicas, nunca a apreciaram. Os adversários políticos atacaram os seus gastos e consideravam-na autoritária.

\footnotetext{
1 Silveira, L. E. e FERnANDES, P. J., 2006, p. 106-114.

2 Para todas estas questões, ver LOPES, M. A, 2011.
} 
$\mathrm{Na}$ verdade, Maria Pia era uma mulher inteligente, muito generosa e com grande intuição política. A ela se devem os maiores entusiasmos populares pela dinastia e as óptimas relações estabelecidas entre Portugal e Itália nas décadas de 1860, 1870 e 1880. A ela se deve, também, a resolução de questões graves no reinado do filho (1889-1908). Todavia, porque agiu sempre discretamente, quando o seu papel não foi propositadamente ocultado, a historiografia portuguesa não se tem apercebido da sua real importância política, o que aqui se pretende salientar.

\section{Família e infância}

A princesa Maria Pia nasceu em Turim a 16 de Outubro de 1847, no seio da família reinante de Sabóia, a Casa donde tinha saído, no século XII, D. Mafalda (ou Matilde), esposa do $1^{\circ}$ rei português ${ }^{3}$. A menina era neta do rei da Sardenha-Piemonte, Carlos Alberto de Sabóia (1798-1849), e filha do príncipe herdeiro Vítor Manuel (1820-1878) e da sua mulher Maria Adelaide de Habsburgo (1822-1855), arquiduquesa austríaca.

Carlos Alberto de Sabóia, que tão celebrado será pelos Liberais por ter outorgado em 1848 o Estatuto, isto é, uma Carta Constitucional como D. Pedro IV fez em Portugal, foi nos primeiros anos do seu reinado um soberano absoluto e ainda o era quando Maria Pia nasceu. Um ano antes havia sido eleito o papa Pio IX, que nessa altura augurava excelentes relações com os Sabóias. O novo papa considerava o Piemonte um "pilar da Igreja" ${ }^{4}$ e a Casa de Sabóia "Piíssima", distinguindo-se "pelo seu filial afecto pelos Pontífices Romanos" ${ }^{5}$. Carlos Alberto, devoto atormentado, sempre respeitou a Igreja, e no Verão de 1847, precisamente, tinha apoiado o papa contra a ocupação de Ferrara pelas forças austríacas. Quando meses depois nasceu uma princesinha Sabóia nesta corte tão rigidamente piedosa $^{6}$, nada mais natural que o sumo pontífice a tivesse apadrinhado.

\footnotetext{
3 Ver capítulo 1 deste livro.

${ }^{4}$ Cognasso, F., 2002, p. 623.

5 Carta do papa Pio IX a Vítor Manuel, de Outubro de 1847. Cit. por MONTI, A., 1939, p. 148.

${ }^{6}$ Cf. Gentile, P., 2009.
} 
Foi sem dúvida Carlos Alberto, rei e chefe da família, a decidir essa escolha de tanto significado político e foi através do pai que Vítor Manuel soube que o papa aceitara apadrinhar o filho que iria nascer ${ }^{7}$. Nasceu uma filha, às 6 h da manhã do dia 16 de Outubro. O parto foi rápido e o nascimento deixou a mãe feliz, pois desejava uma menina ${ }^{8}$. Nesse mesmo dia, às 17 h30m, foi baptizada solenemente, sendo o padrinho representado pelo núncio papal. A cerimónia foi "brillantissima" sob todos os aspectos, nas palavras do mestre de cerimónias?.

Em 1847 o reino da Sardenha era constituído pela ilha do mesmo nome, pelo Piemonte onde se localizava a capital do reino, Turim, pela antiga república de Génova e ainda pelo condado de Nice e o ducado da Sabóia, territórios que actualmente integram a França. A aspiração a uma unidade política da Itália era já bem viva, sustentada por monárquicos liberais e por republicanos. Os Sabóias serão os condutores dos primeiros, conseguindo fazer da península itálica um reino unido sob um regime parlamentar. Será uma causa exaltante, de feição romântica, conduzida pelo ministro Cavour e pelo rei Vítor Manuel II. Um processo longo, culminando em 1870 com a ocupação de Roma, doravante a capital da Itália. Maria Pia viverá tudo isto de longe. Verá a sua pátria, que ama entranhadamente, construir-se gradual e gloriosamente, ignorando-a a ela, uma Sabóia, filha do fundador, sem que em nada possa intervir.

Carlos Alberto iniciou a expansão territorial na direcção da Lombardia, atacando os Habsburgos que a governavam e que eram a sua própria família, mas foi infeliz. Derrotado em Novara, em Março de 1849, abdicou do trono e saiu precipitadamente de Itália. Dirigiu-se para Portugal. Extenuado e doente, o ex-rei da Sardenha morreu no Porto a 28 de Julho de $1849^{10}$. Este fim conferiu-lhe uma aura romântica que fez esquecer as suas tergiversações.

\footnotetext{
${ }^{7}$ SAVOIA, V. E., 1966, p. 141, carta de Vítor Manuel ao papa de 16.9.1847.

8 Carta de Renato de Habsburgo (avô materno de Maria Pia) a Vítor Manuel, datada de 17.10.1847. Cit. por MONTI, A., 1939, p. 153.

9 Biblioteca Reale di Torino, STP 726-15: Registro dei cerimoniali di corte... Devo e agradeço o conhecimento desta fonte ao Professor Pierangelo Gentile, que me facultou a transcrição.

10 Ver capítulo 8 deste livro.
} 
Maria Pia tinha, pois, 17 meses quando os pais subiram ao trono, a 24 de Março de 1849. A Casa de Áustria, que era a sua família materna, tinha relações difíceis com os Sabóias porque dominava a Lombardia e o Veneto, territórios vizinhos do Piemonte, e, ainda, através de diversos membros da família, tutelava várias outras unidades políticas da península itálica (como a Toscana). No processo de unificação italiana os Habsburgos serão, a par do papa, os grandes adversários. Mas quando Vítor Manuel se casou, não começara ainda a expansão piemontesa. E a noiva foi uma austríaca como, afinal, também, já era a sua mãe, Maria Teresa de Habsburgo (1801-1855). Vítor Manuel e Maria Adelaide eram primos direitos, sendo ambos Sabóias e Habsburgos. Não só Carlos Alberto se unira a uma austríaca, como uma irmã dele, Maria Isabel de Sabóia-Carignano (1800-1856), se consorciara com o arquiduque de Áustria, Renato (Rainier) de Habsburgo (1783-1853), vice-rei da Lombardia-Veneto e filho do imperador Leopoldo II da Áustria. Maria Isabel e Renato eram os pais de Maria Adelaide. Maria Pia era, pois, Habsburgo, tanto pelo lado paterno como pelo materno. Durante a sua vida adulta manterá correspondência e relações de afecto com os parentes austríacos.

Quando Maria Pia nasceu, tinha a mãe 25 anos e o pai 27. Estavam casados desde 1842 e já existiam os irmãos Clotilde (1843-1911), Humberto (1844-1900), Amadeu (1845-1890) e Otão (1846-1866). A seguir a Maria Pia, Maria Adelaide deu à luz três outros rapazes que não sobreviveram, numa sucessão de partos demasiado próximos. A família real, que habitava em Turim, era constituída, depois do exílio e morte de Carlos Alberto, pelo jovem casal reinante e seus filhos, pela rainha-viúva e por Fernando de Sabóia (1822-1855), irmão de Vítor Manuel e duque de Génova, e sua mulher e filhos: Maria Isabel da Saxónia (1830-1912) e os filhos Margarida (1851-1926), que será a $1^{a}$ rainha de Itália, e Tomás Alberto (1854-1931). Era ainda viva uma bisavó, a mãe de Carlos Alberto, Maria Cristina da Saxónia-Curlândia (1770-1851).

A família materna era mais numerosa, mas estrangeira e residindo longe. Pouco tempo depois do nascimento de Maria Pia, as relações familiares degradaram-se por motivos políticos. Quando a princesa nasceu, viviam ainda os avós Renato e Isabel, além de Maria Cristina, que era bisavó tanto 
pelo lado paterno como materno. Os tios Áustrias eram cinco: Leopoldo (1823-1898), Ernesto (1824-1899), Segismundo (1826-1891), Renato (1827-1913) e Henrique (1828-1891). Pela linha materna, Maria Pia era bisneta do imperador da Áustria Leopoldo II, irmão de Maria Antonieta. E entroncava também nos Bourbons, pois Leopoldo de Áustria casara com a infanta Maria Luísa, filha do rei de Espanha Carlos III. Também pelo lado paterno Maria Pia descendia dos mesmos. Maria Pia era, pois, parente, e não muito longínqua, de D. Luís de Bragança, seu futuro marido, neto de Maria Leopoldina de Habsburgo e por isso trineto de Leopoldo II. De forma mais clara: a mãe de D. Maria II era prima direita da mãe de Maria Pia. Os genealogistas, que tanto esquecem os ramos femininos, aparentemente nunca se deram conta disto.

As duas rainhas da Sardenha, Maria Adelaide e Maria Teresa, vieram a morrer quase em simultâneo, em Janeiro de 1855. Adelaide, que tinha sido mãe pela $8^{\text {a }}$ vez na semana anterior, foi ao funeral da sogra, a 16 de Janeiro. No regresso, vindo de carruagem, sentiu-se mal. Faleceu quatro dias depois. Vivera dividida pela lealdade devida aos dois clãs Habsburgo e Sabóia, que se tornaram inimigos. Acresce, para infelicidade e terror de Maria Teresa e Maria Adelaide, que desde 1850 se temia a excomunhão de Vítor. Maria Adelaide era uma mulher carinhosa, como revelam as suas cartas para o marido ${ }^{11}$ e para o pai. Em Março de 1848, conta a este último que na véspera a pequenina Maria saíra pela primeira vez à rua e que estivera nos jardins do palácio com todos os irmãos ${ }^{12}$. Em Maio transbordava de ternura para com a sua filha mais nova: "Marie devient tous les jours plus jolie" 13 .

Subitamente, no intervalo de um mês, entre Janeiro e Fevereiro de 1855, a tragédia abateu-se sobre a família. Maria Pia perdeu a mãe, a avó e o tio Fernando. Em Maio morreu também o irmão recém-nascido. No ano anterior, em Junho, tinha falecido outro irmão, Carlos Alberto, que nascera em 1851, o seu "querido irmãozinho Carlos, de quem muito gostava", como Maria Pia

\footnotetext{
11 Cf. MONTI, A., 1939, p. 441-484.

12 MONTI, A., 1939, p. 444.

13 MONTI, A., 1939, p. 455.
} 
escreverá em 17 de Setembro de 1862, em carta ao noivo, ao evocar estes dois meses terríveis ${ }^{14}$.

Maria Pia cresceu a falar três línguas: o francês que era utilizado pelos cortesãos; o piemontês, falado pelo povo, pelos criados e com frequência por Vítor Manuel; e o italiano, o idioma que os Sabóias tinham de dominar, agora que o Piemonte almejava unificar a península. Era nesta língua que pai e filhos se correspondiam, mas com a mãe falariam em francês, idioma que Maria Adelaide e Vítor Manuel usavam entre si. Após a morte da mãe, a educação da princesa passou a ser supervisionada por uma antiga dama da rainha, a marquesa Paulina Pallavicini e pela condessa Natalia de Foresta, mas a menina cresceu sob os cuidados directos da condessa de Villamarina, que era auxiliada por Daria Salasco e por Camila de Foras ${ }^{15}$. À excepção de Otão, que era deficiente físico, os filhos de Vítor Manuel receberam uma educação rígida, muito severa. Clotilde e Maria Pia no palácio real de Turim, quase reclusas, e Humberto e Amadeu em Moncalieri, em ambiente castren$\mathrm{se}^{16}$. O pai tinha pouco ou nenhum tempo para eles e o afecto que Maria Pia recebeu vinha-lhe dos irmãos, da sua aia condessa de Villamarina e da professora de pintura, Virgínia Panizzardi. Maria Pia guardou para sempre alguns bilhetes de infância que Amadeu lhe dirigiu. Um, de 1855, em que lhe chama "Sorellina"; outro, de Janeiro de 1858, em que a trata por "Mi cara Marghi" e lhe recomenda, brincalhão, "come e dorme bem mas não rebentes"17.

Os resultados da pesquisa em arquivos italianos foram decepcionantes para o conhecimento da infância de Maria Pia. Mas esta trouxe para Portugal cadernos escolares $^{18}$ que permitem conhecer o ensino que lhe foi ministrado. Os mais antigos, que não são os primeiros do seu percurso escolar, datam de Março de 1857, tinha a princesa 9 anos, e prolongam-se até 1861. Como os cadernos estão em Lisboa, teria havido o propósito de a fazer prosseguir

\footnotetext{
${ }^{14}$ Arquivo Nacional da Torre do Tombo (ANTT), Arquivo da Casa Real (ACR), cx. 7335. Carta integralmente publicada por SILVEIRA, L. E. e FERNANDES, P. J., 2006, p. 50. Os documentos do ACR serão localizados apenas pela caixa porque, tendo trabalhado a partir de documentação digitalizada, não possuo informação dos $n^{\text {os }}$ das capilhas.

15 LOURO, F., 1987, s.p.; DE PAOLI, G., 1995, p. 139.

16 DE PAOLI, G., 1995, p. 139.

17 ANTT, ACR, cx. 7344.

18 ANTT, ACR, cxs. 7489 e 7490.
} 
a formação interrompida pelo casamento? Nas negociações matrimoniais nunca se aludiu à continuação dos seus estudos, à necessidade de lhe nomear professores ou de permitir que os anteriores a acompanhassem.

A 14 de Março de 1858, a princesa Maria Pia, então com 10 anos, ofereceu ao pai um caderno, primorosamente apresentado, com as provas realizadas nas diferentes disciplinas que estudara: Caligrafia, Italiano, Francês, Alemão, História da Sabóia, Cronologia, Geografia e Mitologia. As matérias eram leccionadas em francês, à excepção das línguas italiana e alemã, obviamente. Além destas disciplinas, entre 1857 e 1860, Maria Pia estudou Cosmografia, Aritmética, Geometria, Noções de Física (esta ensinada em italiano), Análise Gramatical, Poesia Francesa, Literatura Italiana, História da Igreja, História Sagrada, História da Antiguidade (começando na Assíria), História de França, História Geral e Instrução Religiosa. Sobreposta à educação literária, eram-lhe incutidos os valores e comportamentos próprios de mulher - a docilidade, a abnegação, o autocontrolo, a suavidade - e a aprendizagem de saberes imprescindíveis a uma princesa: "lavores femininos", que no seu caso incluiu dobar e costurar, canto, dança, piano, pintura, desenho, equitação e caça. Vemos, portanto, que carecem de fundamento as afirmações sobre a sua educação negligenciada. O que sucedeu é que foi interrompida demasiado cedo.

Vítor Manuel queria expandir o reino para a Lombardia, sob os Habsburgos. Para isso precisava do auxílio de Napoleão III, imperador dos Franceses. Este, considerado um parvenu pelas outras famílias reinantes, impôs como condição o casamento do primo Napoleão Jerónimo ${ }^{19}$ com Clotilde de Sabóia e os Italianos viram na anuência da princesa uma imolação à pátria. O historiador Antonio Monti considerou-a, depois do pai, "o melhor fruto" da Casa de Sabóia oitocentista, figura a merecer "grandioso monumento nacional"20. O seu colega Francesco Cognasso afirmou que o sim da princesinha fez a Itália ${ }^{21}$. Eduardo Brazão, por sua vez, escreve que se tem

19 O seu verdadeiro nome era Napoleão José Bonaparte, mas Napoleão III exigiu que se identificasse como Napoleão Jerónimo para se distinguir dele próprio. Napoleão José era filho de Jerónimo Bonaparte, ex-rei da Vestefália e irmão do imperador Napoleão I.

${ }^{20}$ MONTI, A., 1941, p. 193.

21 Cognasso, F., 2002, p. 645. 
exagerado e romantizado o seu sacrifício. "O que não lhe perdoavam era ele ser um Bonaparte!"22. Seja como for, Clotilde tornou-se uma heroína em Itália, até porque, sendo muitíssimo religiosa, ganhou foros de santidade. Depois, em 1878, regressou ao país natal e não mais de lá saiu. Assim sendo, Clotilde permanece na memória colectiva italiana enquanto Maria Pia, que fez a sua vida em Portugal, está completamente esquecida no país que a viu nascer e morrer.

Em Janeiro de 1859 Maria Pia perdeu, pois, a companhia da irmã, que foi residir na corte francesa. A 8 de Junho, Vítor Manuel II e Napoleão III entraram em Milão. Depois, num movimento imparável, o rei da Sardenha anexou a Marca e a Úmbria, territórios papais. Pio IX excomungou-o a 26 de Março de 1860. O acordo com a França obrigara Vítor Manuel a ceder a esse país o condado de Nice e a Sabóia, território ancestral da família que usava o seu nome. Como teria Maria Pia, então com 12 anos, vivido tudo isto, ela que era educada num ambiente muito religioso e de exaltação da sua linhagem? Finalmente, em Novembro, Garibaldi e Vítor Manuel entraram triunfalmente em Nápoles, desaparecendo o reino das Duas Sicílias.

No ano seguinte, em Fevereiro de 1861, Vítor Manuel convocou o primeiro parlamento do reino de Itália e em Março tornou-se o seu primeiro rei, com o nome Vítor Manuel II, fazendo ressaltar a continuidade da dinastia. Para a unificação total da península faltavam apenas os territórios de Roma e de Veneza, este pertencente à Áustria, cujo chanceler era Renato de Habsburgo, cunhado de Vítor Manuel. Em Junho, o novo reino foi reconhecido pela França e logo de seguida por Portugal, o $2^{\circ}$ país a fazê-lo. Outras nações se seguiram, mas Vítor Manuel era malvisto pelas famílias reais da Europa, tanto pelo seu confronto com o papa e o imperador da Áustria, como por ter destronado o rei de Nápoles. Neste contexto, percebe-se que o rei de Itália tivesse todo o interesse em estabelecer laços estreitos entre a sua Casa e uma outra família reinante católica e constitucional. A família real portuguesa era excelente, até porque Vítor Manuel acreditava que também na Península Ibérica se faria a união política. Portugal podia ser aí o que o Piemonte fora na Itália. E o rei da Ibéria

22 BRAZÃO, E., 1963, p. 357. 
seria seu genro, pois a sua filha mais nova crescia a olhos vistos. Nesse ano, Vítor Manuel diz a Clotilde que se visse a irmãzinha ficaria espantada, pois está mais alta do que ela e muito bonita 23 .

\section{Casamento e nascimento dos filhos}

Em 1861, estando viúvo o jovem rei de Portugal D. Pedro V, circulou o boato, tanto em Portugal como em Itália, de que iria casar com Maria Pia de Sabóia ${ }^{24}$. Os rumores tinham fundamento. Nada fora tratado por parte de D. Pedro, mas o $1^{\circ}$ ministro italiano, Cavour, enviara nesse ano a Lisboa o marquês Caracciolo di Bella para sondar o soberano português. As negociações não avançaram, embora em Itália a ideia não fosse abandonada 25 . Em Paris, Clotilde de Sabóia ouviu também dizer que a irmã iria casar na família real portuguesa e pediu ao pai informações exactas. Este respondeu-lhe a 26 de Outubro dizendo-lhe, talvez mentindo, que a "embrulhada" fora obra dos diplomatas italiano (Nigra) e português (visconde de Paiva) em Paris e do ministro português dos Negócios Estrangeiros (Ávila), sem que ele nem o rei de Portugal o soubessem ${ }^{26}$. A 9 de Novembro Vítor Manuel alude novamente ao assunto, informando Clotilde que "nada mais se soube sobre isso e as coisas continuam nos termos que sabes" 27.

Mas nesse mesmo mês, a hecatombe dos Braganças foi ainda mais impressionante do que a dos Sabóias em 1855. A rainha D. Maria II, que morrera em 1853, deixara duas filhas (Maria Ana e Antónia) e cinco filhos (Pedro, Luís, João, Fernando e Augusto). O seu sucessor, D. Pedro, casou-se em 1858, mas a jovem rainha Estefânia de Hohenzollern faleceu sem filhos no ano imediato. Antes disso, uma das infantas, Maria Ana, fora casada na Saxónia e, na viuvez do rei, casou-se a infanta mais nova, partindo

23 SAVOiA, V. E., 1966, p. 679 e 683, cartas de 11.2.1861 e 13.3.1861.

${ }^{24}$ Textos de Sá da Bandeira cit. por VILHENA, J., 1922, p. 175 e do representante português em Itália, cit. por BRAZÃO, E., 1966, p. 59-60.

25 GHisalberti, A. M., 1940, p. 483.

26 SAVOIA, V. E., 1966, p. 720-721.

27 SAVOIA, V. E., 1966, p. 726. 
para a Prússia. O rei já se decidira passar a segundas núpcias, mas ainda nada fora resolvido. Restavam na corte portuguesa, além de D. Pedro V, o seu pai ${ }^{28}$ e quatro príncipes. Em Novembro de 1861, no espaço de dias, morreram o infante D. Fernando e o rei D. Pedro, provavelmente de tifo. D. Augusto adoeceu gravemente. Os outros dois, D. Luís e D. João, tinham ido acompanhar a irmã recém-casada. Quando regressaram, dois irmãos tinham morrido. D. Luís tornou-se rei e D. João adoeceu a seguir, vindo também a falecer em fins de Dezembro. D. Augusto sobreviveu, mas ficou diminuído. A dinastia corria perigo. Havia, é certo, duas princesas, irmãs do rei, mas não poderiam subir ao trono de Portugal. Não por serem mulheres, porque a lei portuguesa não o impedia, mas porque tinham casado com estrangeiros. Assim sendo, restava D. Luís, que tinha de se casar rapidamente para assegurar a descendência. Vítor Manuel de Itália, como todos, sabia isso perfeitamente e sabia também que a sua filha já era púbere, constituindo um trunfo político que podia ser usado.

Logo após a morte de D. Pedro, o governo e o rei italianos insistiram na ideia de casar a princesinha com o rei de Portugal, agora D. Luís ${ }^{29}$, aclamado a 22 de Dezembro de 1861. Desse mesmo dia data uma exposição do marquês de Sá da Bandeira, ministro da guerra, aconselhando o casamento do rei com a princesa Maria Pia de Sabóia ${ }^{30}$. Sá da Bandeira invocava interesses nacionais e dinásticos e lembrava que "entre as casas soberanas católicas" havia algumas que não podiam ser contempladas devido aos princípios políticos absolutistas que professavam. Entendia que casar o rei nas famílias de Saxe-Coburgo e de Hohenzollern não traria quaisquer vantagens políticas. Escolher a família de Orleães, inimiga do imperador dos Franceses, poderia acarretar a má vontade dele e tornar-se pretexto para a sua hostilidade. Assim, parecia-lhe ser a princesa de Sabóia a melhor opção. "Esse enlace seria em Portugal muito popular, como

\footnotetext{
${ }^{28}$ Fernando de Saxe-Coburgo-Gotha, intitulado rei D. Fernando II, era apenas rei-consorte. Era primo da rainha Vitória de Inglaterra e de seu marido Alberto, todos Saxe-Coburgo e sobrinhos de Leopoldo II da Bélgica.

29 Ver carta de 2.12.1861 do representante de Portugal em Turim ao ministro português dos negócios estrangeiros em BRAZÃO, E., 1966, p. 57.

30 Cit. por VilhenA, J., 1922, p. 174-175.
} 
mostrou a imprensa periódica liberal, quando correu o boato de que o senhor Dom Pedro havia escolhido aquela princesa, e esta popularidade provém de que a Casa de Sabóia tem dado, desde 1848, as maiores provas da sua adesão ao regime constitucional”. Por outro lado, acrescentava, havia interesse em estabelecer relações de intimidade com a Itália, porque tendo Portugal questões em África com a Inglaterra e a França, e não sendo a Itália uma potência colonial, poderia vir a tornar-se uma aliada que servisse de mediador ou árbitro, pois seria bem aceite pelas outras duas.

D. Luís não acatou o alvitre nem se apressou. Em Março aconselhou-se com a "tia" Vitória de Inglaterra. Como não gostava dos Sabóias, esta considerou que uma aliança com essa família era a que menos convinha, devido à política e sobretudo ao carácter moral de Vítor Manuel II; além disso, afirmava, a princesa era demasiado jovem. Preferia Maria de Hohenzollern, mas temia que os pais, muito abalados com a morte da filha mais velha (Estefânia, rainha de Portugal), não consentissem nessa união. Se não fosse esta possível, a melhor escolha era Teresa, filha do arquiduque Alberto da Áustria ${ }^{31}$. Entre Janeiro e Junho de 1861 os jornais portugueses tanto garantiam que o rei casava com Maria de Hohenzollern, como com Teresa de Habsburgo ou com Maria de Sabóia. O ministro Sá da Bandeira insistia nesta última, mas D. Luís escolheu a princesa austríaca, o que desagradou ao ministério, que era de esquerda liberal e via com muitos maus olhos uma aliança com os Habsburgos, que de forma alguma podiam ser considerados uma bandeira da liberdade política. A questão resolveu-se porque o arquiduque recusou a pretensão do rei de Portugal, escudando-se na juventude da filha 32 .

A 16 e 17 de Junho as câmaras dos deputados e dos pares aprovaram a dotação da futura rainha, cujo nome não foi mencionado, e D. Luís pediu a mão de Maria Pia de Sabóia em carta escrita a Vítor Manuel no dia $18^{33}$, sabendo que seria aceite. É que os contactos com Itália tinham prosseguido. Vítor Manuel leu a missiva a 3 Julho e deve ter informado a filha no

\footnotetext{
31 PAIXÃO, V. B., 1965, p. 14-15; SILVEIRA, L. E. e FERNANDES, P. J., 2006, p. 38. 32 PAIXÃO, V. B., 1965, p. 18-19; SIlVEIRA, L. E. e FERNANDES, P. J., 2006, p. 39.

33 ANTT, ACR, cx. 7341. Pub. na íntegra por Silveira, L. E. e FERnANDES, P. J., 2006, p. 40.
} 
próprio dia, como declarou, pois no dia 4 o conde de Nigra (prefeito do palácio) procurou Borges de Castro (representante diplomático de Portugal) para lhe perguntar, a mando de Maria Pia, "quais eram as princesas da família real que residiam em Lisboa e em que relações se achavam para com S.M." ${ }^{4}$. As informações prestadas pelo representante de Portugal não eram animadoras para uma princesinha de 14 anos. É que, embora as relações fossem boas, só viviam em Lisboa a infanta D. Isabel Maria de Bragança, tia-avó do rei, e Amélia de Beauharnais, viúva de D. Pedro IV, avô de D. Luís. Tinham 61 e 50 anos e praticamente não abandonavam as suas residências.

Como prometera, Vítor Manuel respondeu no dia 6 de Julho. E como todos sabiam antecipadamente, respondeu com um sim. Nesse mesmo dia, D. Luís soube por telegrama que Vítor Manuel e Maria Pia consentiam no casamento e que o correio do gabinete seguia no dia seguinte com a carta do rei ${ }^{35}$. Nesta, Vítor Manuel afirmava que o pedido lhe tocara o coração de rei e de pai e lhe agradara profundamente. Consultara a filha que the manifestou o seu inteiro assentimento e "o desejo de poder fazer feliz" o futuro marido. Ele, rei, ao consentir, renovava antigos laços de família e tinha a certeza de que o enlace seria "acolhido com entusiasmo em Itália", onde não se esquecia "a nobre e afectuosa hospitalidade" com que Portugal recebera o seu pai. Referindo-se à filha, afirmava que, apesar da sua "grande juventude", as suas "qualidades de espírito e de coração" e "os sentimentos em que foi educada" faziam esperar que fosse digna do rei de Portugal e do seu amor e que tudo faria para merecer cada vez mais a afeição que o povo português já lhe votava.

Mas Vítor Manuel foi mais longe, longe demais, numa autêntica imprudência política. O último parágrafo antes das saudações finais reza desta forma: "Aproveito, Senhor, esta feliz circunstância para vos desejar, assim como à vossa nação, o cumprimento de destinos gloriosos. Desejo muito que a estrela que até hoje tão favorável foi a Itália, possa também proteger da mesma maneira os povos confiados ao ceptro e à sabedoria de Vossa

\footnotetext{
34 Em BRAZÃO, E., 1966, p. 97-98.

35 ANTT, ACR, cx. 7496.
} 
Majestade"36. Não há dúvida que Vítor Manuel via Portugal como um novo Piemonte que unificaria a península. E queria a sua família ligada a essa glória. Para isso incentivava o futuro genro. É evidente que tal parágrafo não poderia ser do conhecimento público. Que tempestades políticas internas e externas não poderia provocar! O governo de Espanha não se calaria e em Lisboa seria pretexto de imediato esgrimido pelos políticos descontentes. As reacções da Inglaterra e da França também eram previsíveis e é bem possível que D. Luís se visse pressionado a retirar o pedido de casamento e/ou Vítor Manuel a voltar com a palavra atrás. Mas nada disso aconteceu, pois os votos do rei de Itália não chegaram ao domínio público. O casamento foi anunciado oficialmente no parlamento italiano a 11 de Julho de 1862 e no dia seguinte Vítor Manuel informou os outros filhos por telegrama: "O rei de Itália ao príncipe Humberto. Anuncio-te a ti e aos teus irmãos o ajuste de casamento da tua irmã com o rei de Portugal. Estou certo que ficareis contentes"37.

O entusiasmo foi enorme em Itália quando se soube do noivado. Agradava ao povo porque a princesa casava com um rei e não com o primo mal afamado do imperador francês, parente do antigo invasor; aos políticos porque acreditavam que Portugal, país de liberdades constitucionais, seria o Piemonte da península. Ao saber a notícia, a câmara de deputados italianos aplaudiu longamente. Um deputado declarou que seria uma lição para a Espanha. A comissão que foi cumprimentar Vítor Manuel referiu-se aos "gloriosos destinos" que esperavam os dois povos. A deputação do senado italiano, que também aplaudiu, mencionou o sagrado culto à liberdade comum aos dois povos e à alta conveniência política e evocou Matilde de Sabóia, mulher de Afonso I de Portugal, e Isabel, mulher de Pedro $\mathrm{II}^{38}$.

Em Portugal os sectores progressistas rejubilaram com a escolha de Maria Pia. Escreve-se no Archivo Pittoresco: "O enlace da neta de Carlos Alberto, fundador da liberdade de Itália, com o neto de D. Pedro IV, libertador de

36 ANTT, ACR, cx. 7336. Pub. em PAIXÃO, 1965, p. 4-5, SAVOIA, V. E., 1966, p. 746-747 e Silveira, L. E. e FERnANDES, P. J., 2006, p. 41-42.

37 GhisalberTI, A. M., 1940, p. 483 e SAVOia, V. E., 1966, p. 747.

38 O Conimbricense, 26.7.1862, p. 2, 4. Sobre as rainhas Matilde e Isabel, ver capítulos 1 e 5 deste livro. 
Portugal, não podia deixar de merecer o louvor do povo português e o consenso de todas as nações livres"39. Os conservadores reagiram como se esperava. O jornal $A$ Nação anuncia no dia 15 de Julho, sem qualquer benevolência: "A princesa escolhida é filha de um excomungado"40. Maria Pia estava para sempre ideologicamente conotada. Também a rainha Vitória reagiu mal, despeitada por verificar que D. Luís não seguira os seus conselhos ${ }^{41}$.

Foi o visconde da Carreira, camareiro-mor, quem negociou o contrato de casamento, sendo os plenipotenciários de Vítor Manuel o general Durando (ministro dos Negócios Estrangeiros) e o conde Nigra. As negociações foram breves. Carreira foi recebido em Turim a 3 de Agosto e a 9 o acordo era assinado. O Senado e câmara de deputados tinham já aprovado a despesa de 500.000 liras com o dote da princesa (lei de 15 de Julho desse ano).

A correspondência dos jovens Luís e Maria Pia, entre Julho e Setembro desse ano, revela um noivo que procura conquistar a sua prometida, que se impacienta por a conhecer e por lhe tocar e que idealiza um futuro doméstico feliz e pleno de afecto. De início muito contida, a adolescente abre-se cada vez mais e apaixona-se. O próprio Vítor Manuel se apercebe e, na hora da partida, teme que a filha seja magoada pela realidade conjugal. Deixando falar o pai que existia nele, pede bondade e carinho para a filha numa carta que escreve ao genro:

"Meu querido filho

O teu casamento com a minha filha acaba de se celebrar; que o Bom Deus vos abençoe aos dois e eu, pela minha parte, abençoo-vos do fundo do coração e desejo-vos toda a felicidade.

Agora só desejo saber que ela te agrada.

A pobre criança já te ama muito e fará tudo o que puder para te ser agradável, mas sendo ainda tão jovem e tendo ainda tão pouco uso do mundo, peço-te que tenhas compaixão dela e lhe mostres ainda um pouco o que deve fazer.

\footnotetext{
39 Archivo Pittoresco, 1862, p. 305

40 Cit. por Silveira, L. E. e FERnANDES, P. J., 2006, p. 53.

41 Carta de 2.8.1862, cit. por PAIXÃO, V. B., 1965, p. 19-20 e por SILVEIRA, L. E. e FERNANDES, P. J., 2006, p. 41.
} 
[...]

Adeus, abraço-te de todo o meu coração, envia-me um telegrama quando tiveres visto Maria.

Teu pai muito afeiçoado

Vítor Manuel" 42 .

A 4 de Setembro D. Luís anunciou oficialmente às cortes o seu casamento. No dia seguinte o contrato matrimonial foi aprovado por unanimidade nas duas câmaras e a 9 o rei ratificou-o. A comitiva que ia buscar a rainha partiu para Itália quatro dias depois. Turim preparava-se para a cerimónia. No dia 27 de Setembro de 1862 a princesa Maria Pia, com 14 anos e 11 meses, casou-se por procuração na catedral de Turim. O noivo foi representado pelo príncipe Eugénio de Sabóia-Carignano e oficiou o arcebispo de Génova, monsenhor Charvaz. Ao sair da igreja, a adolescente era rainha. Casada com quem não conhecia e rainha de um país que nunca vira, como em geral sucedia a quem se casava com reis. Tornara-se a primeira em dignidade em toda aquela multidão, sendo apenas superada pelo pai. De imediato recebeu as homenagens que a comitiva portuguesa prestava à sua rainha. D. Luís foi informado por telegrama de que o casamento se realizara. Havia agora uma rainha de Portugal. Por todo o reino as fortalezas dispararam salvas de canhão, repicaram sinos, estalaram foguetes, celebraram-se cerimónias religiosas de acção de graças.

A jovem rainha partiu no dia seguinte para Génova, acompanhada pelo séquito português e pela família real italiana. No dia 29 D. Maria Pia deixou a Itália. Seguiram com ela o irmão Humberto, príncipe herdeiro, e os condes de Villamarina. No dia 5 de Outubro, de manhã, a esquadra luso-italiana chegou ao largo de Lisboa. Ao seu encontro seguiram o infante D. Augusto, o duque de Saldanha e os oficiais-mores. D. Augusto era portador de uma carta de D. Luís: "Minha querida e bem amada Maria: Ainda algumas palavras antes de te ver. Estas palavras, contudo, indicam-nos que em breve nos veremos e para sempre. [...] Como serei feliz ao

42 Carta confiada ao marquês de Loulé e parcialmente publicada por SAVIOTTI, G., 1941, p. 97, 100. Original em francês. Tradução minha. 
ver-te, ouvir a tua voz e poder dizer: finalmente, estou junto da minha bem amada Maria. Seguirei pouco depois desta carta. Crê sempre na afeição do teu, todo teu, Luís" 43 .

A corveta, com a rainha, fundeou em Belém onde uma multidão se acotovelava e foi aí que às $3 \mathrm{~h}$ da tarde, embarcando na galeota real, o rei foi ao seu encontro. Conheceram-se, finalmente. Ela viu um jovem louro de olhos azuis e aspecto germânico, uma figura agradável, mas denunciando já tendência para a obesidade. Era e foi sempre de uma grande afabilidade. Não admira que tenha agradado à jovem esposa que, mais tarde, terá confidenciado: "apenas cheguei a Lisboa e vi el-rei, gostei mais dele do que gostava no retrato" ${ }^{44}$. Quanto ao rei, tinha diante de si uma adolescente que, segundo os critérios clássicos, não podia ser chamada uma formosura. Sobressaíam os cabelos fartos e exuberantes, de cor arruivada; "o certo é que os poetas [da época] lhe cantavam mais as glórias da linhagem do que as maravilhas da plástica embrionária". "O tempo ia modificá-la muito", como afirma Malheiro Dias, um seu admirador que não a conheceu nesse tempo ${ }^{45}$. No mesmo sentido escrevera Benevides em 1879: "Era D. Maria Pia de Sabóia muito jovem quando se desposou com o rei de Portugal; o seu físico não era ainda o que depois se mostrou" 46.

Havia que ratificar o casamento, isto é, os noivos deveriam repetir em presença os seus juramentos e juntos receber as bênçãos. Na verdade, Luís e Maria Pia eram já casados. O verdadeiro objectivo da cerimónia era encenar a realeza, proporcionar ao público um espectáculo de glorificação da dinastia, captar a adesão popular. O dia 6 de Outubro de 1862 esteve magnífico. O sol brilhante, o Tejo cheio de navios engalanados e Lisboa enfeitada com bandeiras e arcos triunfais, ofereciam um belo espectáculo. A cidade estava apinhada de gente que viera para assistir aos festejos. Nos dias anteriores, no Porto, havia uma multidão aguardando o embarque, pois

43 Cit. por PAIXÃO, V. B., 1965, p. 23-24. Original em francês. Tradução minha. Maria Pia correspondeu-se sempre em francês com o marido e os filhos. As traduções para português são da minha responsabilidade, à excepção dos trechos publicados por Luís Espinha da Silveira

44 Apud TINOP, 1939, p. 160.

45 DIAS, C. M., $1912^{\text {b }}$, p. 98-99.

46 Benevides, F. F., 2007, p. 625 
esgotaram-se os lugares nos vapores de carreira e na mala-posta ${ }^{47}$. As hospedarias da capital encheram, as janelas alugaram-se. Ao meio-dia, o rei embarcou no Terreiro do Paço e foi no bergantim real buscar a rainha à corveta que tinha fundeado em frente. Embarcaram juntos para terra, rodeados de galeotas, escaleres, embarcações embandeiradas e cheias de gente. O barulho era ensurdecedor provocado pelas salvas no castelo de S. Jorge, nas torres e navios, pelos foguetes, sinos, vivas da população. A câmara municipal mandara erigir no Terreiro do Paço um pavilhão representando o templo de Himeneu. A rainha foi recebida no Cais das Colunas, debaixo do pálio da câmara, e no pavilhão procedeu-se à cerimónia da entrega das chaves da cidade. Depois iniciou-se o cortejo para a igreja de S. Domingos. A catedral andava em obras, que foram aceleradas para permitir que aí se realizasse a ratificação matrimonial, mas não foi possível conclui-las.

Era agora que a multidão se atropelava para ver a rainha que trajava um vestido de seda branca da Hungria, saia sobreposta de renda de Alençon com apanhados na altura de meia saia onde se prendiam laços azuis e brancos, as cores de Portugal. Na fronte, o diadema oferecido pelo noivo e flores de laranjeira entrançadas no cabelo. Organizou-se o cortejo de mais de 300 carruagens e 14 coches da casa real. No total, 108 cavalos e 112 criados de libré. Atrás do último coche, a guarda real dos archeiros. "Fechava o préstito o [...] estado maior e a cavalaria, na força proximamente de mil cavalos. Formavam alas nas ruas do trânsito a tropa de infantaria”48. A cerimónia religiosa, conduzida pelo cardeal-patriarca, iniciou-se às $15 \mathrm{~h}$. Depois da celebração, o mesmo cortejo regressou ao Terreiro do Paço "e no pavilhão viram desfilar as tropas na força de seis mil homens, comandadas pelo duque de Saldanha. Acabada a revista retiraram-se os reis fidelíssimos ao paço da Ajuda com o mesmo préstito". Nas ruas havia arcos e outras decorações. O cortejo chegou ao paço da Ajuda às 20h30m, fazendo todo esse longo percurso entre a multidão que aclamava os reis. "A candura infantil, o agrado e a afabilidade com que a mimosa princesa, alta e esbelta, correspondia às aclamações do povo, que a saudava e vitoriava em todas as praças e ruas

\footnotetext{
47 O Conimbricense, 4.10.1862.

48 Benevides, F. F., 2007, p. 620
} 
do trânsito, granjearam-lhe desde logo as gerais simpatias". "Com a noite começaram os festejos populares, iluminando-se toda a cidade" ${ }^{49}$. Em Coimbra, como em muitas outras cidades, saciava-se a curiosidade pública: "A rainha D. Maria Pia de Sabóia é uma senhora de fisionomia mui agradável, simpática e expressiva. É de elevada estatura e mui airosa. Os seus cabelos são loiros e os olhos vivos e pretos; a sua tez é alvíssima. Todas as pessoas que têm tido a honra de falar a S.M. vêm cativados da sua extrema amabilidade e delicadeza" 50 . Mas ocultava-se o que era considerado um defeito grave: com esta idade Maria Pia era sardenta.

Decorreram mais três dias de gala com as ruas de Lisboa pejadas por uma multidão de milhares de pessoas. "O entusiasmo por este auspicioso enlace tem chegado ao delírio" 51 . A iluminação e os ornamentos das ruas permaneceram até ao aniversário da rainha, que passaria a ser dia de grande gala. A 6 de Novembro, o príncipe Humberto e os condes de Villamarina regressaram a Itália. Era o último elo familiar que se desprendia. Uma furtiva lágrima no rosto da rainha-menina?

Consumada a separação da família de origem, após o atordoamento inicial pelas festas sucessivas, costumes e língua estranhos, pessoas a conhecer e a não confundir, havia que fazer a integração, estabelecer rotinas, iniciar a sua vida de rainha. Maria Pia vivera o seu "estado de margem" neste ritual de passagem definitivo e tão precocemente vivido. Os Sabóias eram unidos e souberam apoiar a irmã mais nova. Clotilde comunica as suas impressões a Otão, o irmão inválido: "Espero que Maria Pia esteja feliz. Luís é muito bom e parece querer-lhe muito bem. Foi muitíssimo bem acolhida em Lisboa e creio que saberá fazer-se amar e venerar por todos; é ainda muito jovem, mas com a ajuda do Senhor tudo correrá bem" 52 . Amadeu escreve-lhe, assim como o fazem a condessa de Villamarina e Virgínia Panizzardi, antiga professora de pintura. E, acima de tudo, D. Luís era uma pessoa delicada e bondosa. Foi, decerto, meigo e cuidadoso com a criança que lhe entregavam.

\footnotetext{
49 Archivo Pittoreco, 1862, p. 244, 305-306.

50 O Conimbricense, 11.10.1862.

51 O Conimbricense, 11.10.1862.

52 Cit. por MONTI, A., 1935, p. 128-129.
} 
Maria Pia foi feliz nesta altura, apesar dos constrangimentos da vida da corte e, sobretudo, das saudades da família e da pátria. Por isso quer os irmãos junto dela, que a visitem em Lisboa. D. Luís faz-lhe a vontade e convida Amadeu, que aceita53. Contudo, esta visita não se concretizou. Amadeu só viria a Portugal em Outubro desse ano de 1863, para o baptismo do sobrinho, quando Maria Pia se sentia exultante de felicidade. Antes disso, a saudade, palavra que irá adoptar no seu francês corrente, ensombrava-lhe os dias. Mas em Março de 1863, respondendo a uma carta do pai, as saudades tinham cedido, face à ternura do marido e à expectativa de ser mãe: "Continuo muito feliz com o Luís, amo-o muito, não creio que se possa amá-lo mais. Ele é tão bom para mim". "Estou tão contente por ir ser mãe brevemente, e vejo com prazer que partilha da nossa felicidade. Também a mim me parece curioso, por vezes, pensar que com 16 anos serei já mamã" 54 . Meses depois, o jovem casal permanecia muito apaixonado. A rainha, então grávida de 7 meses, escreve ao marido a 30 de Julho:

"Há já um século que não te vejo, meu amor. Vem depressa ter com a tua pequenina que te ama tanto e que não pode ficar sem ti [...]. Dói-me um pouco a cabeça e sinto náuseas, estou certa que é do desgosto de não te ter aqui, meu bem-amado [...]. Amo-te tanto, meu amor, bem o sabes, estou tão feliz contigo e só te tenho a ti, meu amigo. Pensas em mim? Amor, oh!, amo-te tanto que penso constantemente em ti, meu tudo" 55 .

Em carta não datada, mas possivelmente desta mesma altura, D. Luís trata-a por "querido amor" diz-lhe que a ama muito, que longe dela não sente prazer em nada. Numa outra chama-lhe "Ma bonne petite"," e "amour de ma vie" 56.

53 Cf. Arquivo da Universidade de Coimbra, Espólio Martinho da Fonseca, VI, $3^{\mathrm{a}}$, 1, 3, cx. 14, sem $\mathrm{n}^{\circ}$, carta de 23.1.1863.

54 Archivio di Stato di Torino (AST), Legato Umberto II, $1^{\circ}$ versamento, cartella 31. Agradeço aos Doutores Marco Carassi e Federica Paglieri do Archivio di Stato di Torino o profissionalismo e a simpatia com que me atenderam e que tanto facilitaram esta investigação. Não localizei as cartas que D. Maria Pia recebeu do pai. Estarão no Palácio Nacional da Ajuda, cujo acesso me foi vedado?

55 Carta pertencente ao arquivo particular de Humberto II. Extracto publicado em LOURO, F., 1976, p. 182. Tradução minha.

56 ANTT, ACR, cx. 7488. A $1^{\text {a }}$ em Silveira, L. E. e Fernandes, P. J., 2006, p. 60. 
Maria Pia deu à luz no dia 28 de Setembro de 1863. Quinze minutos depois os lisboetas ouviam 101 tiros de canhão que anunciavam o nascimento de um príncipe. Um rapaz saudável que nenhuma apreensão provocava. Os familiares ausentes foram de imediato informados por telegrama. Vítor Manuel enternece-se com a filha mais nova. Em resposta a Clotilde que lhe enviara uma fotografia do filho, diz-lhe: "a pobre Maria, que é ela própria uma pequenita, acaba de fazer, também ela, um outro pequenito" 57 . O baptizado solene do príncipe herdeiro realizou-se na igreja de S. Domingos a 19 de Outubro, mas Maria Pia não compareceu, conforme os usos da época. Só agora foram conhecidos os nomes do príncipe e os pais fizeram uma inovação que, de imediato, escandalizou: o primeiro nome seria Carlos. É óbvio que Maria Pia estava por trás disso, pois Carlos era um nome desde há muito usado na Casa de Sabóia. A jovem rainha já se impunha e não devem ter sido poucas as pressões que sofreu por causa do nome do herdeiro da Coroa.

A 31 de Julho de 1865, D. Maria Pia teve o seu segundo filho. O novo infante foi chamado Afonso Henriques, o que, evocando o $1^{\circ}$ rei português, recordava a $1^{\text {a }}$ aliança entre os Sabóias e a Casa reinante portuguesa. Adivinha-se qual seria o nome escolhido, se em vez de Afonso tivesse nascido uma menina. Mas haverá, muito mais tarde, uma Mafalda na Casa de Sabóia, sobrinha-neta de Maria Pia, que esta apadrinhará.

Segundo as regras de etiqueta, os segundos filhos deviam ter como padrinho o avô materno. Quando nasceu D. Afonso, em 1865, D. Luís e D. Maria Pia receberam pressões para que não convidassem Vítor Manuel por estar excomungado e por se recear uma reacção papal. D. Luís não se importou e convidou o sogro para apadrinhar o filho, mas Vítor Manuel, demonstrando igual cortesia, declinou o convite para não criar embaraços a Portugal ${ }^{58}$. Dois meses depois, os monarcas portugueses foram visitá-lo a Itália e levaram consigo o príncipe herdeiro.

57 SAVOIA, V. E., 1966, p. 764.

58 Cf. ANTT, ACR, cx. 7335. O padrinho veio a ser Napoleão III, para grande contrariedade da madrinha, Amélia de Beauharnais, que detestava o imperador dos Franceses, apesar de serem primos coirmãos. 
Maria Pia nutriu sempre um grande afecto pela família, o que foi crucial para as relações dos dois países. Apesar dos esforços papais para que as relações entre Portugal e Itália se rompessem, isso nunca aconteceu durante o reinado de D. Luís. O que se deve à união das duas famílias reinantes e à personalidade de Maria Pia. E também do rei, há que sublinhar-se, que sempre apoiou a esposa e estimava a família italiana.

\section{O magnetismo da rainha e as viagens a Itália no reinado do pai}

A partir dos 18 anos e até à viuvez, aos 42 anos, Maria Pia impressionava pelo seu porte majestático, elegante e amável. O povo simples estava conquistado pela beleza, sorriso e fama de caritativa. Os mais selectos rendiam-se: "a soberana reúne todas as graças de mulher, dignidade e nobreza da rainha e os requintes da mais simpática amabilidade”, escreve Benevides em 1879, "entre todas as damas das diversas classes sobressai e distingue-se sempre Maria Pia de Sabóia; é verdadeiramente rainha pela graça, majestade e elegância, como o é pela sua posição a consorte do chefe de estado". Segundo ainda este testemunho, "há muitos retratos de Maria Pia de Sabóia; não há, porém, nenhum que se possa dizer perfeito como semelhança" ${ }^{59}$. O mesmo afirma, muito mais tarde, Malheiro Dias, que considera que a rainha não teve a sorte de ter sido bem retratada por um pintor ou escultor genial, pois ninguém conseguiu captar "o seu inolvidável poder de ofuscação"60. A princesa Rattazzi, que esteve em Portugal em 1876 e 1879 e publicou o seu livro em finais deste ano, descreve-a desta forma: "Naturalmente distinta, bem que um pouco caprichosa, encanta toda as pessoas que merecem o singular favor de querer a rainha agradar-lhes. Sem que se lhe possa chamar formosa, há na linha ondulante do seu corpo traços prestigiosos de uma beleza incontestável. De manto de corte suspenso do ombro, como geralmente o usa, em vez de partir da

\footnotetext{
59 BENEVIDES, F. F., 2007, p. 625.

60 DiAS, C. M., $1912^{\text {b, }}$, p. 98.
} 
cintura, raras mulheres terão como ela o grande ar majestoso e imponente" ${ }^{\text {. }}$. Também a nora, quando a conheceu em 1886, salienta no seu diário: "Nenhuma mulher tem um ar mais régio e mais imponente" 62.

Quando os reis portugueses fizeram a sua primeira viagem ao estrangeiro, em 1865, Maria Pia estava já transformada, impressionando ambientes tão exigentes e cosmopolitas como o de Biarritz, onde então se encontrava a corte imperial francesa. Relata Prosper de Merimée: "Tivemos a visita do rei e da rainha de Portugal. O rei é um estudante alemão muito tímido; a rainha é encantadora. Lembra muito a princesa Clotilde, mas para melhor; é uma edição corrigida. Tem a tez de um rosa e de um branco raros, mesmo na Inglaterra. É verdade que tem os cabelos ruivos, mas de um ruivo muito escuro, agora na moda. É muito amável e polida"63.

Com o príncipe D. Carlos, que iam apresentar ao avô, e numerosa comitiva, os reis tinham saído de Portugal a 3 de Outubro. Depois de visitarem os imperadores franceses, chegaram a Turim no dia 25. Mas Turim deixara de ser a capital da Itália, que era agora Florença, enquanto se sonhava com Roma. Assim, depois de terem passado quase um mês no Piemonte, havia que organizar a recepção que um rei faz a outro rei, o que só podia ser na capital. Dirigiram-se, pois, para Florença, onde foram solenemente recebidos e instalados no palácio Pitti a 22 de Novembro, quatro dias depois da abertura do Parlamento. Vítor Manuel quis que fossem recebidos com magnificência real. Um cortejo de coches levou-os da estação ao palácio. "O aspecto juvenil, a fisionomia aberta e sorridente da filha de Vítor Manuel, conquistou os florentinos de imediato. A nova capital viu pela primeira vez todo o esplendor da corte de Sabóia e regozijou-se com ele: a população festejou muito os soberanos de Portugal e os outros príncipes, atropelando-se nas ruas à sua chegada, apesar da chuva forte e persistente" ${ }^{94}$. Foi em sua honra que na improvisada capital da Itália se realizou o primeiro baile de corte, a 25 de Novembro. No dia seguinte os reis portugueses partiram

\footnotetext{
61 RATTAZZI, 1997, p. 86.

62 Cit. por CATINOT-Crost, 2000, p. 62

63 Cit. por ORTIGÃO, $1992^{\mathrm{c}}$, p. 65-66.

64 PESCI, 1904, p. 80.
} 
para San Rossore (Pisa) ${ }^{65}$. A 2 de Dezembro saíram de Itália, rumo a Paris. Tinham estado em Turim, Florença, Génova e Milão. Vítor Manuel ofereceu-lhes jantares, bailes e caçadas, o município de Turim um concerto, os de Florença e Milão bailes.

O ano de 1866 foi muito difícil para D. Maria Pia. A 22 de Janeiro faleceu o irmão Otão, com 19 anos. A dor da rainha deve ter sido enorme, pois Maria Pia sempre votou aos seus um amor incondicional. Em Junho, rebentou a guerra entre a Itália e a Áustria que arrancou o Veneto ao domínio austríaco. Vítor Manuel avisara a filha, logo em Abril, que o conflito estava iminente e que celebrara com a Prússia um tratado secreto de aliança ofensiva e defensiva ${ }^{66}$. Maria Pia sentiu uma angústia imensa e vibrou de patriotismo. Como ela desejaria ser homem e estar lá em combate! Mas não era. Não tinha qualquer papel a desempenhar na construção do seu país. A 2 de Junho escreve a Virgínia Panizzardi: "Meu Deus, que coisa terrível é a guerra! Oh pobres Italianos! Queira Deus que a guerra se possa ainda evitar; eu ainda o espero. Rezo constantemente pelos Italianos e pela minha família; não podendo infelizmente participar da sua sorte, desejaria ao menos estar em Itália, junto dos meus. Mas esta distância, neste momento, faz-me realmente mal. Oh, como os invejo por poderem dar a sua vida pela Pátria! Como eu daria com alegria a minha vida pela Itália..." ${ }^{67}$. Contudo, a guerra foi breve e vitoriosa para a Itália. A rainha de Portugal pôde sossegar e, no dia do $1^{\circ}$ aniversário de Afonso, que era de grande gala pelo juramento da Carta Constitucional, uma esplêndida festa na Ajuda anunciava a bonança. Não por muito tempo. Neste ano de 1866, D. Maria Pia sofreu um aborto espontâneo. As informações veiculadas pelo paço foram parcimoniosas, o que envolve este acontecimento em algum mistério. A gravidez não fora anunciada, nunca se esclareceu qual o tempo de gestação e o dia exacto em que ocorreu o aborto. Mas, muito provavelmente, terá acontecido a 27 de Novembro e o feto teria entre 5 a 6 meses. Que a criança estava sem vida ao nascer, não pode oferecer dúvida, pois caso contrário

\footnotetext{
65 FIORENTINO, 2008, p. 28.

66 SAVOIA, V. E., 1966, p. 872.

67 Cit. por MONTI, A., 1935, p. 134-135.
} 
teria sido de imediato baptizada e inumada no panteão real como infante de Portugal. Sem baptismo, não podia ser sepultada em solo sagrado. Terá sido isso o que aconteceu? Este episódio está envolto em segredo e pouco mais consegui apurar sobre ele. Mas no último dia do ano Vítor Manuel não conseguia ainda "dissimular a inquietação que lhe causara a notícia do mau sucesso de S.M. a rainha"68. Sequelas ou não deste aborto, D. Maria Pia não voltou a engravidar, o que para ela foi um desgosto. Desejava uma filha, que nunca teve. Dez anos mais tarde escrevia, num momento de tristeza, ser "uma grande pena não haver uma princesinha no palácio"69.

A partir de 1867, a saúde de Maria Pia começou a ressentir-se. Queixas físicas, mas também períodos de desânimo. Vão suceder-se as viagens por indicação médica. Prescreviam-lhe o uso de águas termais e distracções. O rei quis viajar com ela na Primavera desse ano, mas foi impedido, face às críticas dos jornais e do próprio pai. D. Luís cancelou a viagem. Vítor Manuel insistia em que fossem ao casamento de Amadeu, que se realizaria a 30 de Maio. Pediu à filha que se o marido não pudesse ir, como ele gostaria, lhe pedisse autorização para ir sozinha porque desejava muito vê-la e tê-la com eles ${ }^{70}$. A rainha partiu no dia 4 de Maio. Uma carta dirigida a D. Luís por João de Simas, médico da corte que acompanhou a rainha, parece caracterizar uma depressão ${ }^{71}$. Maria Pia entrou em Itália por San Michele e Susa e seguiu para Turim onde chegou às $22 \mathrm{~h}$ do dia 24. Estavam na estação os irmãos e o príncipe de Carignano. Esperavam no palácio o rei e a duquesa de Génova. O pai conduziu-a aos seus antigos aposentos ${ }^{72}$. No dia 30 realizou-se o casamento de Amadeu com Maria Vitória dal Pozzo della Cisterna, pertencente a uma família da velha aristocracia piemontesa.

D. Maria Pia permaneceu algum tempo em Itália, mas queria o marido junto dela e também a este lhe apetecia viajar. Contudo, os constrangimentos políticos eram grandes. Nos primeiros dias de Junho a rainha conformara-se

68 Informação do ministro de Portugal em Itália, cit. por BRAZÃO, E., 1966, p. 238.

69 AST, Legato Umberto II, $1^{\circ}$ versamento, cartella 16. Carta, em francês, de Delfina Grisi Rodoli em que ela repete essa confidência da rainha (datada de quinta-feira de Páscoa de 1876).

70 SAVOIA, V. E., 1966, p. 1179, carta de 29.4.1867.

71 ANTT, ACR, cx. 7335. Carta datada de Paris, 14 de Maio [1867].

72 BRAZÃO, E., 1966, p. 331-335. 
com eles. Em carta a D. Luís diz-lhe que se não puder não venha, que cumpra o seu dever como rei. Custa-lhe muito, "mas tu tens mais paciência do que eu, meu querido. Tenho muita pena, mas ficará para outra vez. Diz-me a verdade e eu regressarei, porque agora estou contente por ter revisto os meus e espero que a minha saúde possa restabelecer-se tão bem aí como aqui". Talvez, acrescenta, seja possível a D. Luís ir a Itália para o casamento de Humberto. Refere-se ainda a um convite para visitar o papa, acerca do qual ainda não falou com o pai porque lhe aborrece ir lá. Dirá que a sua saúde não lhe permitiu ir "et voila tout arrangé", conclui despachada73. A 3 de Julho D. Luís iniciou, finalmente, a sua desejada viagem ao estrangeiro. D. Maria Pia dirigiu-se de Turim para Veneza e daí para Genebra, onde se reuniu ao marido. Juntos, os reis de Portugal seguiram para Paris. A 11 de Agosto os reis iniciaram o regresso a Portugal. Maria Pia tinha feito furor no mundo da moda. Dois estabelecimentos parisienses ter-se-ão depois valido do seu nome para promover as suas criações, surgindo o "Chapéu Maria Pia" da modista Herst e o "Foulard rainha de Portugal" da Malle des Indes.

Em Abril de 1868 a rainha voltou a sair para o estrangeiro. A viagem tinha dois propósitos: assistir ao casamento do irmão Humberto com Margarida de Sabóia, sua prima direita; e fazer uma cura em Bad Ems, no Hesse, estância termal em voga. Mais uma vez D. Luís ficou retido em Lisboa, não se realizando os projectos do ano anterior sobre a sua ida a Itália para assistir ao casamento do cunhado. A rainha partiu de comboio para Itália com D. Carlos, então com 4 anos, no dia 12 de Abril. D. Luís, D. Fernando e D. Augusto acompanharam-nos até à fronteira. A 14 de Abril, o Diário de Notícias (DN) noticiava: "El-rei chorou ao despedir-se da consorte e do filhinho, causando-lhe sobretudo dolorosa sensação o melindroso estado de saúde da rainha". Depois de uma paragem em Madrid, a comitiva chegou a Nice no dia 15, embarcando de imediato para Génova. Aportou aí na manhã de 16 e, horas depois, a rainha chegou a Turim, recebida com todas as honras e aclamada pela população. Em telegrama ao genro, Vítor Manuel comunica-lhe que Maria acabou de chegar e que está bem de saúde, nem parecendo sequer fatigada, mas na semana seguinte

73 ANTT, ACR, cx. 7335, carta sem data. 
informa o seu representante em Lisboa que a rainha está muito fraca e esgotada, a precisar urgentemente de ir para as termas ${ }^{74}$.

$\mathrm{Na}$ cerimónia nupcial do príncipe herdeiro de Itália, a 26 de Abril, D. Maria Pia apresentou-se pelo braço do pai. As duas Coroas mostravam outra vez a sua união. Na noite do dia seguinte saiu de Turim para Florença, onde chegou na manhã de 28, incógnita, como desejou. A 30 de Abril os recém-casados fizeram a sua entrada solene na capital, onde as festas se prolongaram durante uma semana. A rainha de Portugal "honrou com a sua presença aquelas festas, posto que o seu estado de saúde exigisse que delas se abstivesse" 75 . As festividades prosseguiram em Génova. Maria Pia foi convidada pelo síndico, mas declinou, agradecendo, devido à sua falta de saúde que não lhe permitia maiores fadigas. Permaneceu em Florença duas semanas. Depois prosseguiu para Veneza, onde chegou a 15 de Maio, tencionando aí estar até 21, mas, acedendo à vontade da família, ficou até 28 para assistir aos festejos matrimoniais, pois os noivos andavam em périplo, celebrando o casamento nas principais cidades, numa encenação de respeito pelas antigas autonomias de um país recém-unificado.

O DN de 7 de Maio noticiou que D. Maria Pia iria a Roma com o fim único de apresentar o herdeiro da Coroa de Portugal a Pio IX, padrinho da rainha. Rocha Martins repete a informação acrescentando que depressa, no meio da agitação e alegria, "perdeu essa vontade"76. Mas terá sido assim? Nas cartas que escreve ao marido, D. Maria Pia nunca manifestou qualquer vontade de ver o papa. Muito pelo contrário. Nas duas vezes em que tal hipótese foi formulada, no ano anterior e em 1883, já com Leão XIII, ela não o desejava.

A 11 de Maio a ausência da rainha provocava controvérsia na câmara dos deputados. No projecto ao discurso da Coroa a sua demora foi censurada de forma muito elegante, mas o deputado Carlos Testa, defensor da causa do papa, foi mordaz. Os ânimos empolgaram-se, pois falar de Maria Pia era falar de Liberalismo, da política de Vítor Manuel e do poder temporal do papa. O deputado Santos Silva responde inflamado: "A Itália, gloriosa no

\footnotetext{
74 SAVOIA, V. E., 1966, p. 1312.

75 Carta do representante de Portugal em Itália em BRAZÃO, E., 1966, p. 385.

76 MARTINS, F. R., 1926, p. 18.
} 
seu passado, grande no seu presente, e que tem diante de si um brilhante futuro, que não há-de ser indiferente aos destinos da civilização, aos povos continentais da Europa e às grandes conquistas da liberdade democrática, que é o alvo a que miram as modernas sociedades, a Itália, Sr. presidente, merece e há-de sempre merecer as simpatias de todos os homens verdadeiramente liberais. A câmara, prestando as suas homenagens à rainha de Portugal, fazendo votos por que a sua viagem seja mais um feliz ensejo para se estreitarem os laços de amizade que unem dois povos e duas dinastias, e mostrando desejos por que o regresso de Sua Majestade e o do príncipe real se não faça por muito tempo esperar, cumpriu o seu dever”. E conclui: "Desenganemo-nos e desengane-se o ilustre deputado que, apesar da sua má vontade, a Itália há-de ser poderosa, há-de ser livre, há-de ser uma das grandes potências da Europa, porque esses são os seus destinos"77.

O périplo da rainha continuava. Sentia-se mal e acreditava que as termas a podiam ajudar. No dia 28 saiu de Veneza em direcção a Munique. O acolhimento que por toda a parte recebeu "não podia ser mais lisonjeiro, nem mais cordial", conclui o representante de Portugal em Itália78. "Aclamavam-na; chamavam-lhe: "la reine rousse», a designação que lhe dera Ludovic Halevy"79. Durante 20 dias fez os seus tratamentos em Ems. Depois de passar por Paris onde visitou a irmã Clotilde, regressou a Lisboa a 2 de Julho. Mas antes disso reviu o marido que, por gentileza ou propaganda dinástica, foi com o irmão esperá-la à fronteira.

A rotina da corte recomeçara. Havia que desempenhar o seu papel de rainha, dirigir a educação dos filhos, a vida do palácio, as aparições em público.

\section{Problemas políticos e diplomáticos}

Em Setembro de 1868 rebentou a revolução espanhola e D. Luís e D. Maria Pia foram sugados para o centro da "questão ibérica". À excepção

\footnotetext{
77 Actas da Câmara dos Deputados, 11.5.1868.

78 Em BRAZÃO, E., 1966, p. 386.

79 MARTINS, F. R., 1926, p. 19.
} 
do duque de Montpensier, um Orleães, todos os nomes propostos para rei de Espanha eram parentes muito próximos de D. Maria Pia: marido, filhos, sogro, cunhado (Augusto), concunhado (Leopoldo de Hohenzollern), irmão (Amadeu) e primo direito (Tomás). E foi no âmago das conspirações que a rainha partiu para Baden, em Junho de 1869. Que foi fazer? Uma mera cura termal? Emissária secreta para convencer os cunhados Hohenzollern a aceitar o trono espanhol? A rainha desejava, pelo contrário, demovê-los para que o marido se tornasse rei da Ibéria? Seria uma iniciativa dos dois ou iria incompatibilizada com o rei e para o pressionar? A veneração que Andrade Corvo (diplomata e político que se opôs tenaz e indignadamente ao iberismo) sempre sentiu por Maria Pia, faz afastar estas últimas hipóteses. O que terá sido o teor das conversas entre Maria Pia e o imperador Napoleão III, em Paris, antes de prosseguir o seu trajecto? Segundo Rocha Martins, que acredita ter tido esta viagem da rainha o único propósito de convencer os cunhados Hohenzollern a aceitar o trono de Espanha, foi em Baden que ela, através dos grão-duques, entabulou os contactos que ninguém podia perceber ${ }^{80}$. Nada encontrei que o comprovasse.

De Baden, Maria Pia partiu para Itália. Na manhã de 5 de Agosto chegou a Monza. O pai encontrou-a muito bem de saúde, o que não esperava, pois, como diz ao seu presidente do conselho, os telegramas do rei de Portugal fazem sempre supor que a rainha está a morrer ${ }^{81}$. Deslocou-se D. Maria Pia a Itália apenas para rever os seus? Foi transmitir ao pai o resultado das suas diligências? Desejava regressar a Itália definitivamente, como se afirmava, desgostosa com a vida conjugal? Pretendia convencer Amadeu e Tomás a recusar o trono espanhol? Ou, pelo contrário, pressioná-los a aceitar? Os documentos disponíveis impossibilitam esclarecer o assunto. O teor da carta ao marido, escrita em Baden, não deixa adivinhar nem conluios políticos, nem especial desejo de estar em Itália. Pelo contrário, D. Maria Pia demonstra vontade de regressar rapidamente ${ }^{82}$. Este é o período mais obs-

\footnotetext{
80 MARTINS, F. R., 1926, p. 23-24.

81 SAVOIA, V. E., 1966, p. 1441, carta de 11.8.1869.

82 ANTT, ACR, cx. 7335.
} 
curo na vida da rainha Maria Pia, tanto a nível pessoal como político, para o qual há mais interrogações do que respostas ${ }^{83}$.

É conhecida pelo nome de "Saldanhada" uma revolta militar chefiada pelo duque de Saldanha na noite de 18 para 19 de Maio de 1870. O episódio é quase inaudito, pois o velho marechal atreveu-se a comandar um corpo militar rebelde e a ir, altas horas da noite, atacar o paço da Ajuda para obrigar o rei, pela força, a destituir o ministério. A opinião pública foi de repúdio. Em relação à atitude da rainha, os comentários e boatos foram unânimes num aspecto: ficou indignada, manteve-se serena e não perdoou a Saldanha, o que lhe manifestou com toda a altivez e coragem. Quanto à forma como lhe demonstrou a sua indignação, as versões são divergentes: desde os que relatam que o fez usando a frieza glacial, até aos que afirmam que terá proferido uma frase que ficou célebre e que invariavelmente se lhe atribui, embora não haja uma só testemunha do facto. D. Maria Pia ter-lhe-á dito: "Maréchal, si j'étais le maître, je vous fusillerais sur place" ("Marechal, se fosse eu a mandar, fuzilava-o de imediato"). Os boatos mais inverosímeis chegam a descrever o rei fechado num cubículo, morto de medo, e sem conseguir reagir aos incitamentos da esposa. O certo é que no imaginário da época era à rainha que se atribuía a energia, a altivez, o sentido da honra dinástica e a coragem.

No Archivio di Stato di Torino guarda-se cópia de uma carta de D. Maria Pia ao pai, até agora desconhecida, onde lhe relata com pormenor e ao longo de várias páginas todo o episódio da "saldanhada" ${ }^{4}$. Na versão da rainha, não proferiu a célebre frase para Saldanha, mas mostrou a sua cólera não lhe dirigindo a palavra e afirmando publicamente, depois do golpe, que se fosse ela a mandar, o teria detido. E emite declarações surpreendentes: nos primeiros dias o rei manteve-se firme, mas se não o fizesse ela não estava disposta a permiti-lo e ter-se-ia ocupado do assunto. Antes assumir ela o comando do que deixar a regência nas mãos de Saldanha. Todavia, continua Maria Pia na sua carta, o rei conduz bem as coisas, está firme e

\footnotetext{
83 Ver esta questão com mais pormenor em LOPES, M. A., 2011, pp. 179-184.

84 AST, Legato Umberto II, $1^{\circ}$ versamento, cartella 31. Apresenta-se aqui apenas um brevíssimo resumo. Ver LOPES, M. A., 2011, pp. 184-189.
} 
atento e ela tem prazer em ajudá-lo o mais que pode sem que se saiba que é ela, para o fazer realçar o mais possível. Permanece muito atenta, querendo perceber porque é que as ideias da república começam a subverter, porque se canta o hino à república ibérica, etc.

Em suma: Maria Pia tem apenas 22 anos e está longe de ser a mulherzinha desequilibrada, oca e fútil que tantas vezes nos foi apresentada. Depois, na correspondência que mantém com o marido em 1873, 1875, 1876, 1883, 1886 e 1888, os comentários e conselhos políticos são correntes, demonstrando que habitualmente conversavam sobre questões de Estado, existindo entre eles uma profunda cumplicidade em assuntos políticos. Demonstram também que Maria Pia estava acostumada a aconselhar e a incentivar o rei, utilizando o apelo às suas qualidades, reforçando a sua auto-estima, como uma mãe que transmite coragem e auto-confiança a um filho um pouco inseguro. Ao mesmo tempo, mais uma vez maternal, enchia-o de recomendações sobre a sua saúde física e psicológica ${ }^{85}$. E, contudo, segundo o testemunho da dama de honor marquesa de Rio Maior, referindo-se aos últimos anos do reinado de D. Luís, nunca na sua presença se falava de política. Maria Pia estava certamente a dizer a verdade quando afirma que ocultava o seu papel. Como veremos, o filho utilizá-la-á mais do que uma vez para negociações diplomáticas. Muito poucos o souberam.

Leopoldo de Hohenzollern aceitou a Coroa de Espanha, mas, perante os protestos franceses e tentando impedir a guerra, voltou atrás. De nada serviu, porque ambos os países a queriam. A 14 de Julho o ministro francês retirou-se de Berlim. Começou a guerra franco-alemã e em Setembro a França estava derrotada. O império caiu, os Bonapartes desapareceram da cena política e nascia a $3^{\mathrm{a}}$ República francesa. No mesmo mês, Vítor Manuel entrou em Roma que se converteu na capital da Itália. Desabava também o reino papal. Pio IX, auto-enclausurado no Vaticano, passou o resto da vida a combater os Sabóias. Em Janeiro de 1871 foi proclamado o império alemão. Também a Alemanha estava unificada.

85 Ver análise pormenorizada da correspondência dos cônjuges em LOPES, M. A., 2011, pp. 192-198; 266-269; 305-310. 
Antes de tudo isto, em 26 de Julho de 1870, era dada a notícia oficial que D. Fernando acedia a ser rei de Espanha, impondo algumas condições, nomeadamente a impossibilidade da futura união dos dois países. Como este era o verdadeiro móbil dos Espanhóis ao insistirem nos Braganças, a candidatura morreu definitivamente aqui. Vítor Manuel conseguiu vencer a resistência do filho e Amadeu de Sabóia, duque de Aosta, foi eleito rei de Espanha a 16 de Novembro. Os Espanhóis, após mais de dois anos de busca, tinham encontrado um rei. Vítor Manuel saía vitorioso em toda as frentes: unificara totalmente a Itália, fizera de Roma a sua capital, tinha em Humberto um sucessor, sentara no trono de Espanha o segundo filho. Com Maria Pia e Amadeu, a Península Ibérica era agora do seu sangue. A família Sabóia internacionalizara-se, almejando suceder às antigas Habsburgo e Bourbon. Só um senão tinha ocorrido: a queda de Napoleão III levara a família Bonaparte ao exílio. Clotilde e o marido, até aí no centro da corte imperial francesa, o que não era despiciendo, instalaram-se por uns anos na Suíça.

Amadeu I de Espanha foi infeliz no seu reinado e abdicou em Fevereiro de 1873. De imediato, a República foi proclamada, estando ainda os Sabóias em Madrid. Saíram da cidade de madrugada sem guarda de honra, apanhando o comboio para Portugal porque Amadeu tomara a sua resolução sem ouvir o pai e este reagira mal. O embaixador de Portugal acompanhava-os. Ninguém providenciara víveres e houve que se fornecer nas paragens durante a viagem. Em Badajoz ouviram tiros e vivas à República. Em Lisboa tudo mudou. A família real, o governo e muito povo esperavam-nos na estação, recebendo-os com todas as honras. Estavam agora em família, mas o pesadelo ainda não acabara, pois Amadeu, sem o chamado do pai, não se atrevia a regressar a Itália. Finalmente, recebeu-se um telegrama de Vítor Manuel que aprovava a resolução do filho e o informava de que enviara um couraçado para os ir buscar. Amadeu estava perdoado e tanto ele como Maria Pia devem ter sentido um imenso alívio. A 3 de Março os duques de Aosta e os seus três filhos regressaram a Itália.

A 9 de Janeiro de 1878, com 57 anos, morreu Vítor Manuel II. Portugal homenageou-o. Tanto na câmara electiva como na dos pares se ouviram elogios ao defunto e aprovaram-se votos de pesar. Ambas suspenderam os trabalhos por três dias. A rainha, que não ia ao estrangeiro desde 1869, 
partiu para Itália, levando consigo D. Carlos em representação do rei. Chegou a Roma às 21 h do dia 15 de Janeiro. "Por cá dizia-se que a nossa rainha tentara ver o papa de quem era afilhada, mas que a isso se opusera a Cúria"86. E assim se tem sempre escrito. Mas o que se passou não terá sido isso. Senão veja-se o teor dos seguintes documentos:

No dia 15 de Janeiro, quando a rainha estava apenas a algumas horas de Roma, o marquês de Ávila, presidente do Conselho de Ministros, enviou a D. Luís cópia de um telegrama acabado de decifrar. O remetente não é identificado mas percebe-se ser Costa Cabral, marquês de Tomar, nomeado embaixador no Vaticano. O telegrama informava que Simeone, cardeal secretário de estado, acabava de declarar que, de acordo com as ordens do papa, o embaixador de Portugal não poderia ser recebido no Vaticano sem o prévio conhecimento da resolução a tomar por parte do rei e do governo portugueses sobre se continuariam ou não a ver a família real italiana. Se a resolução fosse afirmativa, o embaixador não seria recebido, "pois que assim é altamente prejudicial à posição da Santa Sé”. O embaixador português respondeu-lhe que naturalmente a resolução seria afirmativa e que, mantendo o papa a sua posição, seria quase certa a interrupção das relações diplomáticas. O cardeal retorquiu que Sua Santidade não transigiria. O diplomata pedia, pois, com urgência, instruções ao governo português sobre a matéria ${ }^{87}$. Aquilo que Pio IX exigia, precisamente quando o corpo de Vítor Manuel se encontrava em câmara ardente, revelava uma insensibilidade absoluta, o "coração de pedra" de que muitos o acusavam. Mas o que o movera tinha sido sempre a razão de Estado. Não se tratava das relações (que nunca houve) entre um padrinho e uma afilhada que nem conhecia ou entre o vigário de Cristo e uma católica.

$\mathrm{Na}$ carta que enviou ao rei, a acompanhar o texto do telegrama, Ávila considerava tratar-se de um "negócio muito grave e não se deve resolver sem séria meditação". Parecia-lhe que a resolução portuguesa só podia ser afirmativa, lamentando que o papa tomasse tal decisão quando a rainha

86 BREyner, T., M., 1930, p. 271. Tomás de Melo Breyner (1866-1933), pertencente a uma família aristocrata e cortesã, frequentou o Palácio Real desde a sua infância. Foi depois, até à República, médico da Casa Real. Sentia pela rainha Maria Pia uma profunda admiração.

87 ANTT, ACR, cx. 7337. 
estava a chegar a Roma. No dia seguinte falaria com o procurador da Coroa, o corpo diplomático e o núncio, considerando que convinha também ouvir o conselho de estado ${ }^{88}$. Mas nesse dia recebeu outro telegrama de Itália, informando que a rainha e o príncipe real estavam alojados no Quirinal ${ }^{89}$, o que, de certeza, tinha sido acordado com D. Luís. Isto é, mesmo que Ávila tivesse veleidades de o impedir para evitar um incidente diplomático, já nada havia a fazer. Ora, no meio desta pendência, quando as relações diplomáticas podiam ser interrompidas a qualquer momento e sabendo Maria Pia (a altiva Maria Pia) que o papa exigia a interrupção de relações entre as famílias reais portuguesa e italiana, é impensável que tivesse solicitado ser recebida por ele.

O funeral de Vítor Manuel II desenrolou-se com grande pompa a 17 de Janeiro. Dois dias depois Humberto I prestou juramento como rei de Itália em grande cerimonial a que assistiu D. Maria Pia. Não foi impensada a presença da rainha de Portugal na coroação de Humberto. O papa era abertamente desafiado nas suas exigências de ruptura entre as duas casas reinantes. Menos de um mês após o óbito de Vítor Manuel, faleceu Pio IX, estando D. Maria Pia ainda em Roma. Em Portugal corria a anedota que tinha sido Vítor Manuel que pedira a Deus que o chamasse porque não lhe recebera a filha. A rainha não se demorou em Itália, partindo no dia 10 de Fevereiro.

Tem-se sempre escrito, também, que durante outra sua estada em Roma, cinco anos depois, D. Maria Pia quis ser recebida por Leão XIII e que este recusou. Uma vez mais a correspondência da rainha para o marido apresenta uma versão diferente 90 . Segundo o relato de D. Maria Pia, a questão foi levantada a propósito de uma eventual recepção pelo papa a uma das suas damas. A rainha permitia-a, sendo pedida na qualidade de portuguesa e não de sua dama. Mas Augusto de Andrade, encarregado de negócios na Santa Sé, e o cardeal Di Pietro, protector da igreja de Santo António dos Portugueses, terão conversado sobre um possível encontro do papa e da rainha.

\footnotetext{
88 ANTT, ACR, cx. 7337.

89 ANTT, ACR, cx. 7337. O Quirinal era a residência oficial dos reis de Itália, em Roma.

90 ANTT, ACR, cx. 7335. Carta datada de Roma, 17.6.1883.
} 
Di Pietro perguntara porque é que ela não pedira para ser recebida pelo papa e sugerira que D. Maria Pia se encontrasse com o sumo pontífice, como por acaso, ao visitar o Vaticano. Ao sabê-lo, D. Maria Pia comunicou a Matias de Carvalho (diplomata junto do governo do rei de Itália) que não queria esse encontro, pois só aceitava ser recebida como rainha de Portugal. Nunca pedira para estar com o papa nem dessa possibilidade falara com quem quer que fosse. Por isso não achava bem, comunica a D. Luís, que Di Pietro e Andrade comentassem essa eventualidade, o que qualifica como criancice deste último. A rainha fez saber aos diplomatas que se o papa desejasse vê-la, que lhe mandasse dizer, reservando-se ela o direito de responder, depois de consultar o rei em Lisboa. Contudo, ressalvava, só acederia ao encontro se fosse exigível por um caso extremo. E mesmo assim - afirmava esta mulher tão altiva - talvez ela não o quisesse.

Em conclusão: a crer nas palavras de D. Maria Pia, nunca ela pediu nem desejou ser recebida por Leão XIII, assim como este não a convidou. O incidente, que a rainha desvalorizou, ou assim quis dar a entender a D. Luís, teria sido provocado por inépcia dos diplomatas. Ou, quem sabe?, por maquiavelismo da Santa Sé. De facto, os sectores católicos mais conservadores exultaram porque o papa recusara receber a rainha. E assim se tem continuado a afirmar.

\section{Maria Pia, uma rainha amada}

Na monarquia constitucional a função de rainha-consorte ia muito além da produção do rei seguinte. Para garantir a dinastia era preciso destruir veleidades absolutistas e republicanas. E para cativar os cidadãos as rainhas tornaram-se fundamentais. Os faustos régios dependiam cada vez mais delas, da sua beleza, da sua elegância, da sua simpatia, do seu magnetismo. Reis e rainhas participavam nos grandes espectáculos onde o público os via e com eles partilhava esses momentos. Cabia às rainhas demonstrar o amor

pelo povo e pelos infelizes com as suas obras e festas caritativas; e elas a tudo acudiam, belas, amáveis, compassivas. Isto é, as rainhas eram peças-chave para a popularidade dos reis e solidez das dinastias. 
Foi na segunda metade do século XIX que em Portugal as mulheres se iniciaram na direcção das actividades beneficentes. Burguesas e aristocratas assim irão preencher parte dos seus ócios. As rainhas irão assumir um papel muito visível, fazendo da filantropia o seu pelouro, o que visava projectar uma imagem favorável e conquistar as simpatias do público. Maria Pia inaugurou o modelo. Estefânia também o desejara fazer, mas, se tivesse vivido, dificilmente teria tido o êxito da sucessora, pois a jovem alemã, alma religiosa, não prescindia da doutrinação e da colaboração das freiras, o que era inadmissível para largos sectores da sociedade portuguesa. Maria Pia foi a única rainha do regime constitucional que nesta matéria encarnou aquilo que a nova ordem liberal defendia. Tornou-se a face visível de uma beneficência que se apoiava em organismos cívicos, com rendimentos saídos de subscrições, completamente autónomos de qualquer influência clerical e cuja motivação já não era a caridade por amor a Deus, mas a caridade por amor dos homens, o que, na realidade, era filantropia. Conquistando as populações pelas suas iniciativas, imediatas nos momentos trágicos, e pela simpatia natural, foi uma poderosa arma de propaganda ideológica, dinástica e governamental. A rainha seguinte, Amélia, sempre acusada de beata e jesuítica, nunca conseguiu despertar entusiasmo pela sua obra assistencial.

Imediatamente a seguir à sua chegada a Portugal, por decreto de 27 de Outubro de 1862, D. Maria Pia foi declarada Protectora dos Asilos da Infância Desvalida91. Continuou a presidir a este organismo no reinado do filho. Em 1867 recebeu o título e o encargo de protectora do asilo de mendicidade a abrir brevemente no palácio de Xabregas, o qual por isso mesmo se chamaria Asilo D. Maria Pia ${ }^{92}$. No mesmo ano, foi nomeada protectora da Associação Auxiliadora dos Estabelecimentos de Caridade e Beneficência do Reino93. Em 1875 foi criada em Lisboa a Associação das

\footnotetext{
91 "O asilo proporcionava às crianças pobres de ambos os sexos, geralmente entre os 3 e os 7 a 10 anos, agasalho, educação moral e cívica e instrução elementar. As crianças permaneciam na instituição durante o dia, permitindo aos pais exercer o seu trabalho quotidiano" (LOPES, M. A., 1993, p. 507).

92 ANTT, ACR, cx. 7488.

93 ANTT, ACR, cx. 7488.
} 
Creches sob o patrocínio da rainha. Maria Pia interessou-se sempre pelas creches. Fundou com o seu dinheiro a Creche da Rainha, mudando-lhe o nome para Creche Vítor Manuel quando o pai faleceu. E foi para as creches que organizou a célebre quermesse de 1884. Mas, muito antes disso, tornara-se popular pela sua acção a favor dos inundados do Tejo, em 1876.

Em Dezembro desse ano, a rainha nomeou uma comissão para promover donativos a nível nacional e junto dos portugueses residentes no estrangeiro. Nesta comissão, Maria Pia teve papel activo e não mera presidência nominal. Foram angariados mais de 250 contos (250.351.050 réis) e sobejaram mais de 55. Decidiu-se que o saldo se aplicasse em inscrições para constituir um fundo de reserva para outras calamidades ${ }^{94}$. O numerário fora conseguido através de donativos directos, subscrições nas freguesias e nos estabelecimentos públicos e particulares em todo o território nacional, rifas e récitas por profissionais e amadores. Veio dinheiro de vários países, mas o Brasil suplantou todos. Toda esta movimentação concitara as atenções sobre Maria Pia, que ganhou enorme popularidade. Logo nos primeiros dias de Janeiro de 1877 as câmaras dos deputados e dos pares aprovaram por unanimidade votos de gratidão à rainha pela sua iniciativa. Em Julho a sociedade francesa L'Encouragement au Bien conferiu-lhe a grande medalha de honra. Mas nem todos glorificavam a rainha e nem esta mediática iniciativa impediu a queda do governo de Fontes Pereira de Melo, em Março de 1877 , a quem muitos atribuíam a verdadeira paternidade do programa de angariação de fundos. Ramalho Ortigão troçou dos bailes, saraus, poemas e hinos realizados a favor dos inundados mas, reconhecendo que tanto o partido da oposição como a imprensa e o público louvavam a rainha, teve de concluir que "o trono dos nossos reis acha-se mais firme que nunca no amor dos povos"95.

A quermesse de 1884, outro êxito de Maria Pia, foi realizada na Tapada da Ajuda nos dias 17 a 19 de Maio, com o objectivo de captar fundos para as creches. Esta modalidade de angariação de receitas nunca fora experimentada e a adesão à iniciativa foi enorme e entusiástica. A quermesse foi uma festa

\footnotetext{
94 ANTT, ACR, cx. 7449. Actas das reuniões da Comissão de Socorros aos Inundados.

95 ORTIGÃO, R., 1990, p. 112-113.
} 
e a ideia era precisamente essa: chamar os lisboetas a divertir-se, atraí-los com a presença da rainha e da alta aristocracia, deslumbrá-los com as decorações, a animação e os jogos que decorriam no recinto. Criava-se cumplicidade entre eles e a soberana, promovia-se a fidelidade à dinastia, simulava-se interclassismo e chamava-se a atenção para a importância das creches.

Pela quermesse terão passado mais de 70.000 pessoas. No primeiro dia D. Maria Pia encenou a sua chegada para as $3 \mathrm{~h}$ da tarde. Em elegante toilette branca e acompanhada pelo rei e pelos filhos, foi vitoriada. A música, permanente, acentuava o ambiente festivo. Tinham sido construídos 16 pavilhões cuidadosamente decorados em diferentes estilos. A rainha, no seu pavilhão de feição rústica, vendia flores e as pessoas acorriam para as comprar das suas mãos. Noutros lia-se a sina, vendiam-se refrescos, fazia-se tiro ao alvo e aos pombos, jogava-se bilhar, terciam-se armas. Vendeu-se por todo o país um jornal exclusivo, o Lisboa creche, cujos textos, em boa parte, eram panegíricos de D. Maria Pia. Também o Diario Ilustrado de 17 de Maio de 1884 publicou vários poemas apologéticos da rainha. A 19 de Maio de 1884, ao encerrar a quermesse, a rainha de Portugal estava decerto exausta, mas sem dúvida rejubilava. Quanto ao rei, só tinha a agradecer-lhe. A dinastia vivia um momento alto, bem diferente daquele por que passara precisamente nesse dia há 14 anos.

À excepção dos albergues nocturnos, sob o patrocínio de D. Luís, invariavelmente se pedia o patronato da rainha para as instituições beneficentes que iam nascendo. Os que eram atingidos por calamidades naturais, tranquilizavam-se se lhes prometessem a ajuda da rainha96, os operários em tumulto apelavam para ela ${ }^{97}$, os seus compatriotas nunca a deixaram em paz ${ }^{98}$. Quando a 20 de Março de 1888 um incêndio no Teatro Baquet, no Porto, provocou a morte de 52 pessoas, D. Maria Pia, acompanhada de D. Afonso, partiu para lá, após ter reunido nove contos do cofre de

96 Cf. Actas da Câmara dos Deputados, 17.1.1888.

97 Actas da Câmara dos Pares, 1.2.1889.

98 ANTT, ACR, cx. 7488. Na Biblioteca da Ajuda encontram-se muitos pedidos de auxílio para obras de beneficência, vindos de Itália; no Archivio di Stato di Torino estão as cartas de Virgínia Panizzardi e Camilla e Giuseppina Negri agradecendo as ajudas financeiras recebidas (anos 1870 e 1880); e nos documentos da administração da rainha os registos destes pagamentos. 
beneficência que dirigia, um conto doado por ela e dois pelo rei. Visitou os familiares dos mortos e os feridos, percorrendo as vielas mais esconsas da cidade. Uma das famílias atingidas era a do republicano Alves da Veiga. As autoridades que acompanhavam a rainha vetaram essa visita, mas Maria Pia, como sempre, impôs a sua vontade e entrou em casa do inimigo da dinastia. Foi por esse gesto admirada, como o foi também o republicano que a recebeu com toda a delicadeza. Ao regressar a Lisboa, uma vez mais foi ovacionada, tanto na estação de Santa Apolónia, à sua chegada, como depois, numa récita em benefício das famílias das vítimas, no Teatro de S. Carlos.

A rainha protectora dos aflitos, eis a imagem que Maria Pia conseguira construir. No reinado seguinte, a nova rainha assumiu também esse papel, mas D. Maria Pia nunca deixou de intervir na assistência e ter iniciativas próprias, apesar do grande protagonismo que D. Amélia veio a ter nesta matéria. É evidente que as actividades beneficentes da rainha eram um dos rituais de propaganda da monarquia, para usar uma expressão de Rui Ramos ao referir-se à acção caritativa das rainhas D. Maria Pia e D. Amélia99. Não obstante, creio que a popularidade de D. Maria Pia não advinha apenas da sua capacidade de encenar, que tinha muito apurada, mas porque instintivamente as pessoas percebiam que ela se compadecia de facto, que não era apenas o marketing político que a movia. Por isso se tornava simpática até aos republicanos. Nos inícios da década de 1890, escrevia João Chagas: "No Dispensário criado em Lisboa pela rainha Amélia, recusam-se a receber filhos de mulheres não casadas. Eis uma princesa bem ortodoxa esta nossa rainha! A rainha viúva era menos intolerante e quando se entregava a esse género de sport real, que se chama caridade, não perguntava às mães se eram concubinas. A senhora D. Maria Pia tinha outro conhecimento do mundo!"100. Tinha, de facto, mas era também genuinamente boa, não suportando ver sofrer ou humilhar alguém. Atestam-no episódios que protagonizou e trechos das suas cartas ${ }^{101}$.

\footnotetext{
99 RAMOS, R., 1994, p. 100.

100 CHAGAS, J., 1898 [1893-1894], p. 95.

101 Cf. LOPES, M. A., 2011, passim.
} 
Todavia, D. Maria Pia tinha um grave defeito: era imoderada nos seus gastos, característica que herdara do pai ${ }^{102}$. As compras exorbitantes da rainha de um país pobre eram um óptimo ensejo para a crítica política e o desfavor do público, tornando-se uma ruidosa arma de arremesso nas mãos dos republicanos e dos monárquicos da oposição. Mas, Maria Pia, que tinha um bom "faro" político, talvez percebesse que tais vozes não faziam verdadeira mossa em largos sectores da opinião pública. O povo anónimo sempre gostou de boas encenações da realeza e de rainhas esplendorosas e, de facto, sentia predilecção por D. Maria Pia.

Em Junho de 1880 comemorou-se o tricentenário da morte de Camões, festejos em boa parte promovidos pelo partido republicano. O governo, com receio, mandou escoltar apertadamente a carruagem real. Conta-se que na noite do dia 10, indo os reis para o teatro, a multidão comprimia a carruagem e a escolta, que não conseguiam avançar. Os ânimos republicanos tinham incendiado o povo das ruas de Lisboa. Já havia gritos, protestos, empurrões, gente pisada. O tenente, que comandava a guarda, impacientava-se. Então a rainha abriu a portinhola e ordenou-lhe com serenidade que mandasse abrir a carruagem. A capota foi recolhida e a multidão viu a rainha sorrir e... rompeu aos vivas e às palmas. A ser verídico o episódio ${ }^{103}$, Maria Pia conseguira reverter completamente a situação e revelava, mais uma vez, a sua famosa coragem.

Dois anos depois Maria Pia teve dias de glória. Comemorava-se o centenário da morte do marquês de Pombal e nenhum membro da família real poderia ser considerado apreciador dos jesuítas. O povo "punha-se a amar estranhamente a rainha - a filha de Vítor Manuel, este ainda maior que Pombal porque vencera o próprio papa - e, com semelhantes legendas que ao paço agradavam, os republicanos, se por um lado excitavam as multidões, por outro perdiam terreno ante as admirações populares pela soberana"104. Maria Pia tornara-se um ícone das liberdades constitucionais.

102 Cf. DE PAOLI, G., 1995, p. 291, 300; SMITH, D. M., 2008, p. 92.

103 É relatado por F. Rocha MARTINS (1926, p. 88) que não indica a fonte onde colheu a informação. Apresento o episódio com reserva porque o autor gostava de colorir o que contava e incorre em erros com frequência.

104 MARTINS, F. R., 1926, p. 95. 


\section{Morte do rei}

Em Setembro de 1889 D. Luís estava seriamente enfermo. A doença era, provavelmente, sífilis. Os reis estavam em Sintra, como sempre, mas o estado de saúde do monarca agravava-se. Decidiu-se, então, levar o doente para Cascais. Talvez ele o desejasse, amante que era do mar, talvez a rainha acreditasse que, animando-o, conseguia a recuperação. D. Maria Pia lutou com todas as forças para curar o marido, mas a doença progrediu irremediavelmente. Poucos acreditavam na cura, mas ela obstinava-se. Dizia-se que controlava todos os que frequentavam o paço, procurando impedir qualquer fuga de informação, mas cresciam boatos de uma agonia medonha, que o rei gangrenava, que lhe cortavam bocados de carne em putrefacção e a exalar um cheiro nauseabundo.

Simultaneamente, crescia a intriga política. Um rei morria e uma rainha era afastada e com eles os seus protegidos. Fialho de Almeida não estaria muito longe da verdade ao evocar "os velhos servidores, receosos de perder o prestígio na corte", os ministros "a duvidar se acharão no carácter do rei novo, aquela amável tolerância com que sempre os recebera o rei", "os chefes da oposição, esfaimados por seis anos de exílio [...] a Igreja que não quer perder o final do acto e a cada momento espreita à porta". "E finalmente a rainha - ia a dizer a imperatriz Frederico - soberba e escultural nas suas grandes roupas, os seus olhos de estátua dolorosa, a palidez de Juno despenhada, arrastando-se sem forças, de sofá para sofá, lassa de vigílias sem conta, alucinada já de ciúme sem refrigério" pelo "destino que a relega, magnífica orgulhosa, à semi-sombra de uma vida subalterna, tão asfixiadora para os predomínios teatrais da sua grande raça"105.

D. Luís morreu a 19 de Outubro de 1889. Tinha 50 anos e D. Maria Pia, com 42 feitos três dias antes, passava a rainha-mãe. Na verdade, o seu título era agora rainha D. Maria Pia e não rainha, como até então, pois em Portugal não se utilizavam as expressões rainha-mãe e rainha-viúva. Fialho de Almeida, este homem tão cáustico e venenoso, mas de talento evidente, visivelmente impressionado com Maria Pia, traçou dela um longo retrato

105 ALMEIDA, F., 1919, p. 129-130. 
emocionado e comovente ao relatar o cortejo, que presenciou, conduzindo o cadáver de D. Luís, de Cascais para os Jerónimos, ao longo de quase seis horas, na noite de 21 para 22 de Outubro ${ }^{106}$. Como outros vultos da literatura portuguesa, Fialho revelou-se, então, completamente fascinado por Maria Pia. Coroado o novo rei, era natural que se fizesse a avaliação do reinado anterior. Para alguns agigantava-se a figura de Maria Pia, agora remetida a segundo plano. Leiam-se as palavras de Fialho de Almeida:

"Poucos monarcas da Europa haverão tido companheira mais inteligente, associada mais hábil, e comediante mais finamente senhora da marcação tronícia e da mis-en-scène dinástica.

No jogo dela, nada vulgar, nem mesmo as brusquerias, nem mesmo as palavras soltas, nem mesmo as toilettes tapageuses da sua última fase de mãe de filhos homens. Sobre um trono de império esta mulher ficaria sem dúvida como um modelo de grande imperatriz. Dizem-no a sua indiscutível grandeza de ânimo, a sua orgulhosa compreensão do prestígio real, a transcendência rara do seu tipo, moldado para o trono com um inolvidável poder de ofuscação, e mais que tudo as suas súbitas intuições da majestade moderna, que é toda artificial como uma criação de teatro. [...] Quantas vezes o ânimo do rei [...] encontrou a seu lado essa varonil figura a ordenar-lhe energia e a sustentar ela só as prerrogativas da Coroa enxovalhada?”.

"Neste reinado neutro de vinte e oito anos, podre de paz e de costumes, com tampas de oiro sobre catacumbas de miséria e vilanagens odiosas sob aparências de progresso e de igualdade, duas figuras apenas conseguem romper a chatinagem comum, aspirar à consagração da estatuária, e adquirir por vezes a grandeza histórica de tipos dominadores e extra-normais. São a rainha e Fontes, os dois verdadeiros mestres, os únicos sinceros amigos que teve S.M. o rei D. Luís.

Maria Pia ensinou o marido a ser rei. Fontes Pereira de Melo ensinou seu amo a ser político. [...] Com o seus conselhos, Fontes deu-lhe força. Com a sua nobreza, a rainha impôs-lhe autoridade"107.

\footnotetext{
106 Almeida, F., 1919, p. 155-169. Também cit. em LOPES, M. A., 2011, p. 316-318.

107 ALmeidA, F., 1919, p. 149-151.
} 


\section{Acção política no reinado do filho}

D. Carlos casara em 1886 com Amélia de Orleães (1865-1951), filha dos condes de Paris, pretendentes ao trono de França. Deste casamento nasceram os infantes Luís Filipe (1887-1908) e Manuel (1889-1932) ${ }^{108}$. Considera Rui Ramos que D. Carlos remeteu a mãe para "o mundo subpolítico", transmitindo sobre D. Maria Pia as conhecidas asserções de desequilíbrio e alguma tolice. Segundo este autor, a rainha-viúva "agarrava-se a tudo o que lhe pudesse dar importância” mas ninguém lha dava ${ }^{109}$. É outra a minha leitura. D. Carlos informava-a de imediato sobre as grandes decisões e problemas políticos e utilizou-a várias vezes como diplomata, servindo-se da sua influência junto dos reis de Itália. Aliás, vários autores coevos e dos anos 1910-1920 perceberam claramente que nunca Maria Pia foi a figura insignificante a quem ninguém atribuía importância. O que sucedia é que D. Carlos era cioso do seu papel e da sua imagem e não lhe permitia iniciativas. Maria Pia manteve-se na sombra, como sempre fizera em assuntos políticos. Acresciam agora os ciúmes de D. Amélia que o marido tinha de gerir.

Em 1892 D. Maria Pia exerceu pela primeira vez a regência do reino. Foram apenas alguns dias, de 9 a 18 de Novembro, por ocasião de uma visita dos reis a Espanha. Nesta altura muitos ânimos andavam ao rubro. João Chagas fora preso, surgira o órgão anarquista $A$ Revolta e, ao embarcar na estação do Rossio a 9 de Novembro, D. Carlos fora publicamente desrespeitado. D. Maria Pia transbordou de actividade nesses poucos dias de regência. Visitou hospitais, prisões, escolas, navios, quartéis e arsenais, num total de 24 instituições ${ }^{110}$. Os jornais publicaram notícias panegíricas,

108 Era afilhado de D. Maria Pia. Foi ela que escolheu o nome. Ao seu primogénito chamara-lhe Carlos, um nome saboiano estranho à Casa real portuguesa, ao secundogénito deu-lhe o nome masculino do primeiro casal que unira as duas Casas. O seu neto e afilhado chamou-se Manuel, onomástico que entrara na casa de Sabóia no século xvi, por intermédio da sua antepassada a infanta Beatriz de Portugal, filha de D. Manuel I (ver capítulos 2 e 3 deste livro), e que agora regressava à família portuguesa reinante.

109 RAMOS, R., 2006, p. 221.

110 ANTT, ACR, cx. 7488. 
mas Fialho troçou impiedosamente das suas iniciativas ${ }^{111}$. Maria Pia agarrava-se a tudo para se dar importância ou percebia que era vital reconquistar afeições e fidelizar militares? É evidente que o programa das visitas, iniciado logo na manhã do dia 10, fora preparado com o governo e com D. Carlos, que deixara às ordens da mãe o seu ajudante de campo. Se é verdade que o rei considerava a mãe precipitada, nunca lhe entregaria a regência sem lhe dar orientações precisas sobre o que gostaria ou não gostaria que fizesse. E se lhe pediu um programa tão intenso, era porque sabia como ela concitava simpatias. Se assim não procedera, é porque confiava no seu senso político. Isto é, de uma forma ou de outra, a acção de Maria Pia não pode ser lida como uma tentativa patética de se atribuir importância.

D. Carlos pediu à mãe muito mais do que cativar a população. Serviuse dela como diplomata, pois na década de 1890 o rei português tinha pouca influência nas cortes estrangeiras. Foi só após a morte da rainha Vitória, em 1901, que a sua amizade com Eduardo VII lhe proporcionou relações privilegiadas. D. Amélia, no campo da política internacional, em nada podia ser útil, mas D. Maria Pia possuía desde sempre uma valia ímpar junto dos reis de Itália. O peso político de Humberto de Sabóia não se resumia ao de um rei de um país europeu, pois a Tríplice Aliança firmada entre a Itália, a Alemanha e a Áustria-Hungria, sucessivamente renovada, conferia-lhe uma influência muito vasta. D. Carlos nunca negociou directamente com o tio Humberto ou com o primo Vítor Manuel III. A interlocutora dos Sabóias foi sempre Maria Pia. Não sendo possível alongar-me aqui, farei apenas um breve apanhado de algumas das suas intervenções diplomáticas.

Em Abril de 1893, D. Maria Pia partiu para Itália. Não saía de Portugal há cinco anos e era a sua primeira viagem ao estrangeiro depois de viúva. O objectivo era muito compreensível, pois fez-se saber, e assim se tem repetido, que ia assistir às bodas de prata do casamento do irmão. Na realidade, ia em missão diplomática junto do rei italiano e do imperador da Alemanha, que encontraria em Roma. A rainha-viúva conseguiu o apoio

111 ALMEIDA, F., 1911, p. 178-181. 
do rei de Itália e do kaiser para que fosse assinado um acordo com os credores externos da dívida pública portuguesa, o que permitiria salvar Portugal da bancarrota ${ }^{112}$. O acordo foi assinado a 20 de Maio de 1893 e a acção da rainha ficou oculta.

Portugal e o Brasil interromperam relações em Maio de 1894113. D. Maria Pia uma vez mais apelou ao irmão. Em carta de 27 de Maio, que a rainha dirigiu em português a Hintze Ribeiro, remete-lhe a resposta do rei de Itália ao telegrama que ela lhe enviara, "no sentido que nós falámos". E diz ao ministro: "Espero que lhe agrade, porque está em tudo tão boa como nós a desejamos. El-rei de Itália ficou ciente de tudo quanto diz respeito a esta questão e porque tudo se fez desta forma" ${ }^{114}$. O que o rei de Itália escrevera à irmã e esta agora comunicava, é que ele e o seu governo já haviam diligenciado, indirectamente e de acordo com as potências aliadas e o governo britânico, para que o diferendo entre Portugal e o Brasil se resolvesse prontamente. Nas versões habituais deste caso, D. Maria Pia é pura e simplesmente omitida.

Ainda no mesmo ano de 1894, D. Maria Pia voltou a agir na sombra a favor de Portugal. Desta vez tentou resolver uma questão colonial em África, cujos resultados comunicou uma vez mais a Hintze. Diz-lhe que acabou de receber a resposta do rei Humberto, seu irmão, a qual "mostra a boa vontade do rei ao respeito do negócio de África”. Espera agora que, com os esforços de Hintze junto da Alemanha, se "possa conseguir tudo o que nós desejamos e que é de justiça". Informa ainda que Crispi, presidente do governo italiano, lhe pareceu também na disposição de ajudar e quer acreditar também na boa vontade do imperador alemão "que estando bem inteirado no negócio nos faça justiça se puder"115.

112 Telegramas de Maria Pia para D. Carlos e para Hintze Ribeiro em AST, Legato Umberto II, $1^{\circ}$ versamento, cartella 16. Ver LOPES, M. A., 2011, p. 330-331.

113 Uns revoltosos brasileiros tinham-se acolhido a um navio português que lhes concedeu protecção. O governo do Brasil não perdoou.

114 Arquivo Regional de Ponta Delgada (ARPD), Arquivo Ernesto Rodolfo Hintze Ribeiro, 3.10.69.R. Carta em português, datada da Ajuda, 27 Maio 1894. Agradeço ao Dr. Jorge Frazão de Mello-Manoel, do Arquivo Regional de Ponta Delgada, as facilidades concedidas para esta investigação.

115 ARPD, Arquivo Ernesto Rodolfo Hintze Ribeiro, 3.11.30.R. Carta em português, datada de Sintra, 14.7.1894. 
Em 1896 foi Maria Pia que conseguiu reatar as relações entre Portugal e Itália, desastradamente quebradas durante um ano. D. Carlos viajara pelo estrangeiro em Outubro e Novembro de 1895. Visitou a França, Alemanha e Inglaterra sem contrariedades, mas com a Itália houve um grave incidente diplomático porque, para não irritar o papa, o rei de Portugal cancelou a ida a Roma. O governo português propôs o encontro dos reis em Monza, mas o de Itália queria-o na capital, como era de esperar. Nenhum cedeu e D. Carlos não foi a Itália. Para resolver o diferendo, e numa acção concertada com o filho e o governo, Maria Pia aproveitou o casamento do sobrinho Vítor Manuel para ir a Roma negociar com o irmão. E conseguiu reatar as relações entre os dois países. Dois telegramas que enviou a D. Carlos e ao ministro dos Negócios Estrangeiros anunciam os bons resultados 116 . A rainha chegou a Roma a 22 de Outubro de 1896 em entrada solene sentada ao lado do rei Humberto. Segundo testemunha local, Maria Pia sorria contente às aclamações da multidão. E o povo romano, que sentia a sua cidade ostracizada por tantos, vitoriou-a. Maria Pia ter-se-á tornado, desde então, muito popular em Roma117. Desta vez, a acção diplomática da rainha não ficou ignorada. Na câmara dos pares, respondendo ao discurso da Coroa, que diluíra muito o papel da rainha-viúva, afirma o conde de Tomar a 26 de Janeiro de 1897: "Não acha clara a maneira por que se diz que foi resolvido o conflito com a Itália; não obstante julga interpretar os sentimentos da câmara prestando homenagem de respeito e consideração a Sua Majestade a senhora D. Maria Pia pelos seus bons ofícios junto de seu irmão o rei de Itália”.

Em Junho de 1901, D. Maria Pia e D. Afonso partiram para Itália para assistir ao baptizado da princesa Iolanda, filha de Vítor Manuel III. D. Maria Pia ia, uma outra vez, em missão diplomática. Conta o $6^{\circ}$ marquês do Lavradio, sem datar o episódio: "Negociava-se o convénio com os credores externos [concluído a 25 de Maio de 1902], e estava então no poder um ministério regenerador, presidido por Hintze Ribeiro [de 25.6.1900 a

116 ANTT, ACR, cx. 7426.

117 Almanach Bertrand, 1913, "A rainha Maria Pia”, p. 23-24. O artigo é apresentado por Fernandes COSTA (1913) como um texto escrito por um correspondente italiano sem identificação do autor. 
20.10.1904]. Realizava-se um conselho de ministros no paço das Necessidades, sob a presidência de S.M. Apenas sentados, el-rei declara ao conselho que, por informações particulares que recebera de Berlim, sabia que o kaiser se opunha à assinatura do convénio, o que era uma fatalidade para Portugal. Lembrou, porém, que estando o kaiser em negociações com o rei de Itália para conclusão do tratado da Tríplice Aliança [ $3^{a}$ renovação, assinada em 1902], S.M. a rainha senhora D. Maria Pia podia partir para a Itália e conseguir que o rei seu sobrinho se interessasse junto do imperador da Alemanha para a assinatura do convénio". Parece óbvio que D. Carlos não teria proposto esta solução sem a ter já debatido com a mãe e acordado que o baptismo oferecia um óptimo pretexto para a viagem. Lavradio prossegue: "Assim foi decidido. S.M. a rainha partiu no dia seguinte para a Itália, e a imprensa da oposição, tanto monárquica como republicana, vociferou contra o esbanjamento dos dinheiros da nação para regozijo da família real; porém, oito dias depois, um telegrama de Roma anunciava a el-rei que o kaiser cedera às instâncias do rei de Itália. A diplomacia de el-rei D. Carlos salvara o país de uma catástrofe"118. Tal como em 1893, a rainha-mãe voltava a conseguir o crédito externo de que o país precisava, sob pena de bancarrota. E o marquês do Lavradio, que enaltece o rei, não diz uma palavra sobre D. Maria Pia.

\section{No reinado do neto: o isolamento}

A 1 de Fevereiro de 1908, o rei D. Carlos e o príncipe real D. Luís Filipe foram assassinados ${ }^{119}$.

A 6 de Maio realizou-se a cerimónia da coroação de D. Manuel II. Em Montemor-o-Velho, como em todos os concelhos, festejou-se a aclamação do rei e a câmara municipal enviou as suas mensagens. Comparem-se os textos dirigidos às rainhas. A D. Amélia: "Sirva de lenitivo à vossa imensa

\footnotetext{
118 ALmeIDA, J., L., 2004, p. 37-38.

119 Ver em LOPES, M. A., 2011, p. 364-368 e 382-388, as palavras e atitudes de D. Maria Pia nos dois momentos terrivelmente dramáticos que viveu em 1908 (regicídio) e em 1910 (partida para o exílio).
} 
dor a certeza de que o coração de todos os portugueses está ao lado do vosso amado filho, no qual fundam as esperanças do ressurgimento de Portugal". A D. Maria Pia: "Com as felicitações pelo dia de hoje, a câmara municipal de Montemor-o-Velho saúda em vossa majestade a estrénua defensora das liberdades constitucionais" (DN, 10.05.1908). A rainha-avó continuava a ser a bandeira dos monárquicos progressistas e a câmara de Montemor proclamava-o de forma quase acintosa para D. Amélia, que há muito se tornara impopular por ser conotada com o clericalismo conservador.

A dor que Maria Pia sofreu com a morte do filho e do neto foi brutal e o restabelecimento lento e com recaídas. Nos 2 anos e 8 meses que se seguiram sucederam-se as aflições e os desgostos. Tudo se desmoronava à sua volta: a dor não passava e a vontade de viver tardava a reaparecer, a saúde ressentiu-se, o neto e a nora não nutriam por ela especial afecto, os regicidas eram venerados por milhares de pessoas, a investigação policial do crime era uma farsa, o avanço republicano evidente. Acrescia a sua situação financeira, calamitosa e impossível de solver. No Parlamento exigiam-se esclarecimentos sobre os seus débitos ao Tesouro e a velha rainha foi citada em tribunal por dívidas pessoais. O rei, seu neto, nada fez para a ajudar. Os seus afectos concentraram-se em D. Afonso. Os dignitários que serviam D. Maria Pia - agora, sim, sem qualquer valimento político e cortesão - reduziram-se ao duque de Loulé, ao veador Benjamim Pinto e às marquesas de Unhão e de Belas. A Ajuda tornou-se um palácio deserto e sombrio, com pessoal escasso recebendo ordens para poupar em tudo. E, última afronta, propalava-se que a "rainha velha" tinha enlouquecido, a tal ponto que regava as flores dos tapetes, contando incessantemente "um... dois... três..." e conversando com os seus mortos - asserção que continua a ser repetida e para a qual não existe uma só testemunha.

Com a sua idade, sem saúde, sem recursos e sem influência, objectivamente D. Maria Pia não tinha qualquer papel político, mas convertera-se num símbolo. Quando se propalou (quem propalou?) a sua loucura, houve quem nela visse a metáfora do naufrágio nacional. Leia-se o drama O Fim de António Patrício. A obra é de 1909 e a acção desenrola-se nessa altura. Maria Pia, velha e louca, vive na miséria, num paço em ruínas, com um du- 
que demente, uma aia lúcida e alguns criados. Foi abandonada e traída pelo neto e pela nora. Lisboa é então bombardeada por estrangeiros. O rei morre e a cidade é vencida. Mas Portugal não é só Lisboa e ainda há uma esperança. Um desconhecido aparece no paço querendo galvanizar o país em torno da velha rainha. Descobre, horrorizado, que não passa de uma louca, uma total ruína física e mental. É o fim de tudo, de um país e de um povo. O autor identificara Portugal e Maria Pia.

A revolução republicana começou na madrugada do dia 4 de Outubro e no dia seguinte foi proclamada a República. A família real reuniu-se em Mafra. Tomás de Melo Breyner recorda: "A rainha Maria Pia queria por força ficar, mas estava de uma serenidade majestosa. Forçada a partir, partiu para o exílio como se partisse para uma viagem de gala. Que grande Senhora!"120. D. Maria Pia saiu de Portugal, precisamente a 5 de Outubro, dia em que chegara ao nosso país no já longínquo ano de 1862. Os Braganças dirigiram-se por mar a Gibraltar, onde aportaram no dia 7. A 16, dia em que completava 63 anos de vida, D. Maria Pia partiu para Itália a bordo do couraçado Regina Elena que o seu sobrinho, rei de Itália, enviara a recolhê-la. Partiu só, sem o filho que lhe restava e que sempre vivera com ela porque Vítor Manuel negou-se, nessa altura, a receber o primo. Era mais um golpe, e terrível, com que a velha rainha não contava. Mas o certo é que D. Maria Pia era membro da família real italiana. D. Afonso, além de não ser assim considerado, era o príncipe herdeiro de Portugal, país que agora era uma República e que nos últimos tempos mantinha relações frias com Itália. Vítor Manuel III e/ou o seu governo evitavam complicações diplomáticas.

\section{O exílio}

Na manhã do dia 19 de Outubro (mais um dia de aniversário, este da sua viuvez), D. Maria Pia e a sua pequena comitiva desembarcaram em Gombo, próximo de Pisa, porque o rei de Itália e a família passavam aí

120 BREYNER, T., M., 1993, p. 316. 
uma temporada, no palácio San Rossore, e o sobrinho quis recebê-la pessoalmente. Enquanto a rainha Helena e filhos esperavam na praia, Vítor Manuel III subiu a bordo a buscar a tia. Foi pelo seu braço que regressou à pátria, ao som das salvas do couraçado. Já não era rainha em Portugal, um decreto de 15 de Outubro considerara proscrita a família de Bragança, mas em Itália foi sempre tratada como rainha. No dia 23, uma ordem emanada pelo Ministero della Real Casa italiana comunicou aos correios e telégrafos que a rainha Maria Pia usaria os serviços gratuitamente como pessoa da família real. Um mês depois especificou-se que a correspondência seria identificada por "Servizio di Sua Maestà la Regina Maria Pia"121.

Logo nesse mês de Outubro, o conselho de ministros português percebeu que não podia ignorar o que fora estabelecido no tratado matrimonial de D. Maria Pia, que tinha direito a uma dotação do Estado. De facto, o seu ordenado fora estabelecido por um tratado internacional celebrado entre Portugal e Itália. E assim, o governo republicano resolveu pagar por inteiro a dotação de D. Maria Pia. O governo declarou-se também disposto a permitir o seu regresso, excluindo-a do exílio imposto aos restantes membros da família real. Isto é, a República Portuguesa proporcionava à velha rainha o que recusava terminantemente às outras pessoas da família real - eis, mais uma vez, Maria Pia no centro das relações entre Portugal e Itália. Desta feita, as relações diplomáticas entre os dois países dependiam da forma como a ex-rainha era tratada pelo governo republicano.

D. Maria Pia ficou em San Rossore até em Novembro. Depois instalou-se no palácio real de Capodimonte, em Nápoles. Vítor Manuel pôs à sua disposição "uma corte civil formada por damas e gentis-homens" (DN, 5.12.1910). O destino de Maria Pia comoveu os Italianos. Afirma um autor não identificado que quando passava nas ruas de Nápoles as pessoas

${ }^{121}$ Archivio Centrale dello Stato (ACS), Ministero della Reale Casa, Segretaria Reale, 1911, busta 541, fasc. 127. Agradeço ao Doutor Aldo Ricci, do Archivio Centrale dello Stato, as facilidades concedidas para esta investigação. 
calavam-se e os homens descobriam-se ${ }^{122}$. Em Dezembro viveu a alegria de rever Afonso. Apesar das saudades que sentia ${ }^{123}$, os últimos meses de vida de D. Maria Pia foram, decerto, de um grande apaziguamento, sobretudo após D. Afonso se lhe ter reunido. O sobrinho Vítor Manuel resgatara-a do isolamento, das angústias e humilhações financeiras, das afrontas privadas e públicas.

A 4 de Junho de 1911, celebrando o cinquentenário do reino de Itália, foi solenemente inaugurado o grande monumento a Vítor Manuel, em Roma. Lá estavam os reis Vítor Manuel III e Helena, os príncipes e as duas rainhas-viúvas: Margarida de Itália e Maria Pia de Portugal. Para D. Maria Pia, há tanto tempo afastada de grandes galas, este dia, de glorificação do pai e da pátria, foi de certeza marcante. E para quantos a viam, pois era a única filha de Vítor Manuel, já que restavam apenas ela e Clotilde e esta teimava em não ir a Roma. Nesse mesmo mês, Clotilde de Sabóia adoeceu gravemente. Maria Pia foi com a cunhada Margarida para o Piemonte. Instalaram-se no palácio de Stupinigi, nos arredores de Turim, e visitaram a doente na sua residência de Moncalieri, ali perto. A 25 de Junho Clotilde faleceu. A irmã não teve forças para assistir ao funeral, realizado dois dias depois.

D. Maria Pia não se restabeleceu. A 1 de Julho recolheu ao leito. D. Afonso, que não acompanhara a mãe ao Piemonte, viajou de imediato para junto dela. D. Amélia também acorreu logo que soube do estado da sogra. Maria Pia teve conhecimento que o filho e a nora estavam a caminho. Ter-lhe-ão ainda dito, para a consolar, que o neto também viajava para Stupinigi ${ }^{124}$. Mas não era verdade. Provavelmente para evitar não ser recebido na qualidade de rei, D. Manuel não quis assistir à agonia nem participar nas cerimónias fúnebres da avó. Embora se afirme usualmente que filho e nora assistiram à morte, a própria D. Amélia confessa que não, que morreu "longe de todos nós". E incorre num estranho equívoco, pois

122 “A Rainha Maria Pia”, Almanach Bertrand, 1913. Como foi ressalvado, estas informações são atribuídas a um correspondente italiano sem identificação da autoria. Terão sido escritas por ocasião da morte da rainha.

123 BREYNER, T. M., 1994, p. 26.

124 “A Rainha Maria Pia”, Almanach Bertrand, 1913. 
diz que D. Maria Pia faleceu no palácio real de Nápoles. O que D. Amélia contou e se tornou célebre, foi-lhe, pois, relatado por outrem ou ela efabulou: que, minutos antes de expirar, D. Maria Pia perguntou para que lado ficava Portugal e quis morrer a olhar na direcção do país onde fora rainha ${ }^{125}$. Realidade ou lenda?

Maria Pia de Sabóia faleceu aos 63 anos de idade às 15 h do dia 5 de Julho de 1911 no seu Piemonte natal. As causas da morte foram, segundo informações da imprensa, patologias hepática e cardíaca. Vítor Manuel III decretou 40 dias de luto da corte. As bandeiras conservaram-se a meia haste durante 5 dias e os camarotes reais fechados. Na corte da rainha Margarida o luto de 3 meses ordenado pela morte de Clotilde passou a 100 dias $^{126}$.

Pelas 13h30m do dia 8, o cadáver foi trasladado de Stupinigi para a igreja Gran Madre de Dio, em Turim. Nas cerimónias fúnebres estavam o filho, a nora, toda a família real italiana, representantes do governo, das câmaras parlamentares e dos corpos militares. Os imperadores da Alemanha e da Áustria-Hungria fizeram-se representar respectivamente pelo adido militar e pelo embaixador em Itália, o rei da Bulgária (um Saxe-Coburgo) enviou o príncipe herdeiro e o governo português o seu representante em Itália (Lambertini Pinto), para desagrado da rainha Margarida, que não gostou que o filho acolhesse o representante da República portuguesa ${ }^{127}$. Compareceram também os cônsules de França, Inglaterra, Estados Unidos, Repúblicas sul-americanas, etc. Depois organizou-se um $2^{\circ}$ cortejo em direcção à estação do funicular que conduzia à basílica de Superga, panteão real dos Sabóias. Era agora uma cerimónia privada. Um vagão fúnebre transportou o ataúde e um outro o clero e as pessoas de serviço. Na basílica, na presença da família real, que tinha ido de automóvel, fez-se de imediato a inumação na cripta régia ${ }^{128}$. Maria Pia repousava, finalmente, junto da família de que tanto se orgulhava.

125 BARROS, L., 1951 , p. 38.

126 ACS, Ministero della Reale Casa, Prefetto di Palazzo, 1911, busta 179, V, fasc. 2.

127 Carta de Lambertini Pinto a João Chagas de 1-8 de Março de 1812 em Correspondência..., 1958, p. 89.

128 ACS, Ministero della Reale Casa, Prefetto di Palazzo, 1911, busta 179, V, fasc. 2. 


\section{Fontes e estudos}

\section{Fontes manuscritas}

Archivio Centrale dello Stato (ACS), Roma

Ministero della Reale Casa, Segretaria Reale, 1911.

Ministero della Reale Casa, Prefetto di Palazzo, 1911.

Archivio di Stato di Torino (AST), Turim

Legato Umberto II, $1^{\circ}$ versamento, cartella 16 (Cartas dirigidas à rainha Maria Pia, 1884-1911)

Legato Umberto II, $1^{\circ}$ versamento, cartella 31 (Cartas escritas pela rainha Maria Pia a seu pai, 1861-1877).

Archives Nationales de France (ANF), Paris

300/AP/III/713/224: diário de D. Amélia de 7 a 16 de Outubro de 1910 (transcrição traduzida e facultada por Margarida Durães).

Arquivo Nacional da Torre do Tombo (ANTT), Lisboa

Arquivo da Casa Real: caixas 6947-7496.

Arquivo Regional de Ponta Delgada (ARPD), Ponta Delgada

Arquivo Ernesto Rodolfo Hintze Ribeiro: cartas da rainha D. Maria Pia e do seu mordomo-mor, o $2^{\circ}$ duque de Loulé.

Arquivo da Universidade de Coimbra (AUC), Coimbra

Espólio Martinho da Fonseca.

Espólio Jardim de Vilhena.

\section{Biblioteca da Ajuda (BA), Lisboa}

51-XII-106; 51-XIII-23; 51-XIII-37; 52-IX-30; 52-XIV-8; 54-V-1; 54-V-3; 54-X-8; 54-X-31; 54-X-32; 54-XIII-22; 232-VI; 233-VIII.

\section{Biblioteca Reale di Torino (BRT), Turim}

STP 726-15: Registro dei cerimoniali di corte diretto da me Pietro Vivaldi Pasqua Duca di S. Gioanni Gran Mastro di Cerimonie di Sua Maestà il Re Carlo Alberto. Principiato addi 25 giugno 1844 e terminato addi 8 febbraio 1848 (transcrição facultada por Pierangelo Gentile). 


\section{Fontes impressas}

Actas da Câmara dos Deputados, 1862-1910. Disponibile in http://debates.parlamento.pt/catalog. aspx?cid=mc.cd. Accede il 11/9/2008.

Actas da Câmara dos Pares, 1862-1910. Disponibile in http://debates.parlamento.pt/catalog. aspx?cid=mc.cp. Accede il 11/9/2008.

Actas da Assembleia Nacional Constituinte, 1911. Disponibile in http://debates.parlamento.pt/ catalog.aspx?cid=mc.cp. Accede il 11/9/2008.

Almanach Bertrand, coord. por Fernandes Costa, Lisboa, José Bastos Editor, 1900-1913.

Almanach de Gotha. Annuaire généalogique, diplomatique et statistique 1887, Gotha, Justus Perthes, 1859-1907.

AlmeIDA, Fialho de (1911), Os Gatos VI, Lisboa, Livraria Clássica.

Almeida, Fialho de (1919), Os Gatos I, Lisboa, Livraria Clássica.

Almeida, José Luís de (Lavradio), coord. (2004), Memórias do sexto Marquês de Lavradio, Lisboa, Nova Ática.

Annuario do Archivo Pittoresco 1864-1866.

Archivo Pittoresco. Semanario Illustrado.

BARRETO, José Trazimundo Mascarenhas (1986), Memórias do marquês de Fronteira e d'Alorna, 5 vols., Lisboa, Imprensa Nacional-Casa da Moeda.

BENSABAT, José Jacob (1929), A verdade dos factos occorridos na villa da Ericeira na occasião da implantação da Republica, Lisboa, Imprensa Africana.

BRAMÃo, Alberto (1945), Últimas recordações, Lisboa, Empresa Nacional de Publicidade.

Branco e Negro.

BRANDÃO, Raul (1925), Memórias II, Lisboa, Bertrand.

BRANDÃO, Raul (1998), Memórias I, Lisboa, Relógio d'Água (1ª ed: 1919).

BREyner, Thomaz de Mello (1930), Memórias do professor Thomaz de Mello Breyner $4^{\circ}$ conde de Mafra, 1869-1880, Lisboa, Parceria Antonio Maria Pereira.

BReyner, Thomaz de Mello (1934), Memórias do professor Thomaz de Mello Breyner $4^{\circ}$ conde de Mafra, 1880-1883, Lisboa, Of. Gráfica.

BreYner, Thomaz de Mello (1993), Diário de um monárquico (1908-1910), s.1., s.n.

BreYner, Thomaz de Mello (1994), Diário de um monárquico (1911-1913), s.1., s.n.

Breyner, Thomaz de Mello (2003), Diário de um monárquico (1905-1907), Porto, Fundação Eng. António de Almeida.

Breyner, Thomaz de Mello (2005), Diário de um monárquico (1902-1904), Porto, Fundação Eng. António de Almeida.

CABral, António (1929), Cinzas do passado.... As minhas memórias políticas, Lisboa, Livraria Popular de Francisco Franco.

CABRAL, António (1930), As minhas memorias politicas. Na linha de fogo, Lisboa, Livraria Popular de Francisco Franco.

CABRAL, António (1931), As minhas memorias politicas. O agonizar da Monarchia. Erros e crimes. Novas revelações, Lisboa, Livraria Popular de Francisco Franco.

CABral, António (1933), Cartas d'el-rei D. Manuel II. O homem, o Rei, o Portuguez. Notícias e revelações. Memórias políticas, Lisboa, Livraria Popular de Francisco Franco. 
CHagas, João (1898), Na Brecha (Pamphletos), 1893-1894, Lisboa, Agencia Universal de Publicações.

COLAÇO, Branca de Gonta (2005), Memórias da Marquesa de Rio Maior, Lisboa, Parceria A. M. Pereira ( $1^{\mathrm{a}}$ ed: 1930).

Colleccção Official da Legislação Portugueza, Lisboa, Imprensa Nacional, 1860-1910.

Conimbricense, $\mathrm{O}$.

Correspondência literária e política com João Chagas, II, Lisboa, Empresa Nacional de Publicidade, 1958.

CORvO, João de Andrade (1870), Perigos, Lisboa, Typ Universal.

Costa, Fernandes, pub. por (1913), "A Rainha Maria Pia”, Almanach Bertrand, Lisboa, José Bastos Editor, pp. 23-26.

CUNHA, Xavier \& PINHEIRO, Raphael Bordalo, dir. (1884), Lisboa creche: jornal miniatura offerecido em beneficio das creches a sua magestade a Rainha a Senhora Dona Maria Pia, Lisboa, David Corazzi.

Diario de Lisboa.

Diario de Noticias.

Documentos politicos encontrados nos palácios reais depois da revolução republicana de 5 de Outubro de 1910. Ed. ordenada pela Assemblea Nacional Constituinte em sessão de 13 de Julbo de 1911, Lisboa, Imprensa Nacional de Lisboa, 1915.

Duas palavras sobre a candidatura de S. M. El-rei D. Fernando ao throno de Hespanha por um Portuguez, Lisboa, Lallemant Frères Typographos, 1870.

Estrella, A. Numero unico. Festa de caridade e bazar. Organisado sob a protecção de Sua Magestade a Rainha, Lisboa, s.n., 1885.

FONTES, Vital (1945), Servidor de reis e de presidentes, compilação de Rogério Perez, Lisboa, Ed. Marítimo-Colonial.

Gazeta de Coimbra.

GUIMARÃES, Ricardo (1863), Narrativas e episódios da vida parlamentar, Lisboa, Typographia Universal.

Illustração Portugueza.

Instituto, $O$.

Jornal de Coimbra.

LEAL, Gomes (1881ª), A Traição. Carta a El-Rei D. Luiz sobre a venda de Lourenço Marques, Lisboa, Campos Júnior.

LEAL, Gomes (1881b), O Hereje. Carta à Raínha a Senbora D. Maria Pia ácerca da queda dos thronos e dos altares, Lisboa, Campos Júnior.

LEAL, Gomes (1900), A morte do rei Humberto e os críticos do "Fim dum mundo", Lisboa, Parceria Antonio Maria Pereira.

LEAl, Gomes (1914), Patria e Deus e A Morte do Máo Ladrão, Lisboa, Liv. de João Carneiro (obra literária)

LENOIR, Lélio (1863), Portugal em 1862, Lisboa, Sousa Neves.

LENOIR, Lélio (1864), Portugal em 1863, Lisboa, Sousa Neves.

LENOIR, Lélio (1865), Portugal em 1864, Lisboa, Sousa Neves.

MACHADO, Bernardino (1905), Da monarchia para a república, 1883-1905, Coimbra, França Amado. 
MARTINS, Oliveira (1924), Dispersos II, Lisboa, Biblioteca Nacional.

Nação, $A$.

Occidente, $O$.

Ortigão, Ramalho (1986), As Farpas I. A Vida Provincial, Lisboa, Clássica Editora.

OrTigão, Ramalho (1988ª), As Farpas II. As Epístolas, Lisboa, Clássica Editora.

ORTIGÃO, Ramalho (1988b), As Farpas III. Os Indivíduos, Lisboa, Clássica Editora.

OrTigão, Ramalho (1989), As Farpas IV. O Parlamentarismo, Lisboa, Clássica Editora.

Ortigão, Ramalho (1990), As Farpas V. A Religião e a Arte, Lisboa, Clássica Editora.

Ortigão, Ramalho (1991), As Farpas VI. A Sociedade, Lisboa, Clássica Editora.

Ortigão, Ramalho (1992a), As Farpas X. Aspectos vários da sociedade, da política e da administração, Lisboa, Clássica Editora.

ORTIGÃO, Ramalho (1992 b), As Farpas XI. Aspectos vários da sociedade, da política e da administração, Lisboa, Clássica Editora.

ORTIGÃO, Ramalho (1992 $)$, As Farpas XIV. Crónica mensal da política, das letras e dos costumes (1873-1875), Lisboa, Clássica Editora.

ORTIGÃO, Ramalho (1993a), As Farpas XV. Crónica mensal da política, das letras e dos costumes (1876-1882), Lisboa, Clássica Editora.

ORTIGÃO, Ramalho (1993b), Farpas Esquecidas I, Lisboa, Clássica Editora.

OrTigão, Ramalho (1993c), Farpas Esquecidas II, Lisboa, Clássica Editora.

ORTIGÃO, Ramalho (1993d), Últimas Farpas, Lisboa, Clássica Editora.

Panorama, $O$.

PATRÍCIO, António (1990), O Fim, Lisboa, Assírio \& Alvim (1ª ed: 1909; obra literária).

QUEIRÓs, Eça de (1987), Uma campanha alegre, 2 vols., Mem Martins, Europa-América.

RATTAZZI, Maria (1997), Portugal de relance, Lisboa, Antígona.

Revista Contemporânea.

RIO MAIOR, condessa de (1852-1889), Correspondência de e para seus filhos, (http://www.ics. ul.pt/ahsocial/gd_riomaior.asp). Accede il 17/2/2008.

RIO MAIOR, condessa de (2005), Correspondência para seus filhos, 1852/1865, estudo, organização e notas de Maria Filomena Mónica, Lisboa, Parceria A. M. Pereira.

SAVIOTTI, Gino (1941), "La Lettera di un suocero al genero (Vittorio Emanuele II a Luigi Re di Portogallo” em Italia e Portogallo, Florença, Vallecchi Editore, pp. 95-102.

SAVOIA, Vittorio Emanuel (1966), Le lettere di Vittorio Emanuele II, ed. Francesco Cognasso, 2 vols., Turim, Deputazione Subalpina di Storia Patria.

SCHWAlBACH, Eduardo (1944), À lareira do passado, Lisboa, Imprensa Nacional de Publicidade.

SIlva, J. Possidónio Narciso da (1865), Descrição das novas salas no Real Palacio da Ajuda. Obras mandadas executar por sua magestade a rainha a senhora D. Maria Pia de Sabóia nos seus reaes aposentos, Lisboa, Typ. Portuguza.

TRIBUNA, A.

Ventura, José Miguel [1862], Portugal e a Italia ou enlace da dynastia de Bragança com a dynastia de Saboya, Lisboa, Silva Junior.

Vilhena, Júlio de (1916), Antes da Republica. Notas autobiográficas, 2 vols., Coimbra, França \& Arménio. 
Vilhena, Júlio de (1917), Antes da Republica. Resposta a um livro póstumo, Coimbra, França \& Arménio.

Vilhena, Júlio de (1922), D. Pedro V e o seu reinado. Novos documentos. Suplemento, Coimbra, Imprensa da Universidade.

\section{Estudos}

ABreu, Jorge de (1912), A Revolução Portugueza. O 5 de Outubro (Lisboa 1910), Lisboa, Casa Alfredo David.

AmARAL, Augusto Ferreira do (1966), A acalmação e Dom Manuel II, Lisboa, Empresa Nacional de Publicidade.

ANGUERA, Pere (2003), El general Prim. Biografía de un conspirador, Barcelona, Edhasa.

ARriaga, José (1911), Os ultimos 60 annos da Monarchia. Causas da Revolução de 5 de Outubro de 1910, Lisboa, Parceria A. M. Pereira.

Aurora, conde d' (1939) - A rainha D. Maria Pia, Porto, s.n.

BAÊNA, Miguel Sanches de (1990), Diário de D. Manuel e estudo sobre o regicídio, Lisboa, Alfa.

BARROS, Leitão de (1951), Duas visitas a Versalhes, 1938-1851, Lisboa, Neogravuras.

BENEvides, Francisco da Fonseca (2007), Rainhas de Portugal. Estudo histórico, Lisboa, Livros Horizonte (1 ${ }^{\text {a }}$ ed: 1879).

BERN, Stéphane (1997), Moi, Amélie dernière reine de Portugal, Paris, Denoël [fiction che, a quanto pare, utilizza fonti].

BRAZ̃̃o, Eduardo (1963), A unificação de Itália vista pelos diplomatas portugueses (1848-1860), Coimbra, Faculdade de Letras da Universidade de Coimbra.

BRAZÃO, Eduardo (1966), A unificação de Itália vista pelos diplomatas portugueses (1861-1870), Coimbra, Faculdade de Letras da Universidade de Coimbra.

CAMACHO, Brito (1927), D. Carlos, intimo, Lisboa, Editora Guimarães.

CÂnCIO, Francisco (1939), Aspectos de Lisboa no século XIX, Lisboa, s.n.

CÂNCIO, Francisco (1940), Lisboa de outros séculos. Cem anos de pitoresco, Lisboa, s.n.

CÂNCIO, Francisco (1943), Lisboa. Figuras e casos do passado, vol. 3, Lisboa, s.n.

CÂNCIO, Francisco (1955), O Paço da Ajuda, Lisboa, s.n.

CÂNCIO, Francisco (1962), Lisboa no tempo do passeio público 1, Lisboa, Imp. Barreiro.

CÂNCIO, Francisco (1963), Lisboa no tempo do passeio público 2, Lisboa, Imp. Barreiro.

CARVAlHO, João Pinto de - ver TINOP.

CATinot-Crost, Laurence (2000), La reine Amélie de Portugal. Le plus beau cadeau que la France ait fait au Portugal, Biarritz, Atlântica.

Cognasso, Francesco (2002), I Savoia, Milão, Corbaccio.

COlAÇO, Branca de Gonta \& ARChER, Maria (1943), Memórias da linha de Cascais, Lisboa, Parceria Antonio Maria Pereira.

CORPECHOT, Lucien (2007), Memórias Inéditas da Rainha D. Amélia, Casal de Cambra, Caleidoscópio. 
Costa, António da, D. (1879), Historia do Marechal Saldanha, Lisboa, Imprensa Nacional.

Costa, Júlio de Sousa e (1943), O rei Dom Carlos I. Factos inéditos do seu tempo (1863-1908), Lisboa, Bertrand.

Costa, Mário (1959), Uma quermesse de caridade na Real Tapada da Ajuda, Lisboa, s.n.

DE PAOLI, Gianfranco E. (1995), Vittorio Emanuele II. Il re, l'uomo, l'epoca, Milão, Mursia.

DiAs, Carlos Malheiro (1905), Cartas de Lisboa, 3 vols., Lisboa, Livraria Classica Editora.

DiAs, Carlos Malheiro (1912a), Do Desafio à debandada. O pesadêlo, Lisboa, Livraria Classica Editora.

DiAs, Carlos Malheiro (1912b), Do Desafio à debandada. Cheque ao Rei..., Lisboa, Livraria Classica Editora.

DIAS, Carlos Malheiro [1912c], Entre precipicios, Lisboa, Empreza Lusitana.

EHRHARDT, Marion (1988), "D. Fernando II visto através das suas cartas à família” em Romantismo. Figuras e factos da época de D. Fernando II, I Congresso Internacional de Sintra sobre o Romantismo, Sintra, Instituto de Sintra, pp. 9-14.

FERRÃO, Carlos (1961), Em defesa da verdade. O regicídio, os adiantamentos, a diplomacia de D. Carlos, Lisboa, Editorial Século.

FERro, António (1954), D. Manuel II o Desventurado, Lisboa, Bertrand, s.d.

Fiorentino, Carlo M. (2008), La corte dei Savoia (1849-1900), Bolonha, Il Mulino.

GARCIA, Emídio (1939), O infante D. Afonso de Bragança, Lisboa, Parceria Antonio Maria Pereira.

GENTILE, Pierangelo (2004), "Beneficenza e defensa. I Savoia a Racconigi attraverso i documenti dell'Archivio comunale", Bollettino della Società per gli Studi Storici, Archeologici ef Artistici, Cuneo, no 130 , pp. 47-72.

GENTILE, Pierangelo (2009), "Le pratiche devozionali alla corte di Carlo Alberto di Savoia", Studi Piemontesi, Turim, 38-1, pp. 173-181.

GHISAlBerTI, Alberto Maria (1940), "Maria Pia di Savoia, Regina di Portogallo" em Relazioni storiche fra l'Italia e il Portogallo. Memorie e documenti, Roma, Reale Accademia d'Italia, pp. $483-488$.

GuEdes, Carmina Correia (2004), A educação dos príncipes no Paço da Ajuda (1863-1884), Lisboa, Ministério da Cultura/IPPA/Palácio Nacional da Ajuda.

LEITÃo, Joaquim (1911), Diário dos vencidos. Subsídios para a historia da revolução de cinco de Outubro, Lisboa, Ed. Autor.

LOPES, Maria Antónia (1993), "Os pobres e a assistência pública” em História de Portugal dir. por José Mattoso, vol. V, O Liberalismo, coord. por Luís R. Torgal e João L. Roque, Lisboa, Círculo de Leitores, pp. 501-515.

LOPES, Maria Antónia (2011), "As grandes datas da existência: momentos privados e rituais públicos" em História da Vida Privada em Portugal dir. por José Mattoso, vol. III, Época Contemporânea, coord. por Irene Vaquinhas, Lisboa, Círculo de Leitores e Temas e Debates, pp. 152-193; 470-473.

LOPES, Maria Antónia (2011), Rainhas que o povo amou. Estefânia de Hohenzollern e Maria Pia de Saboia, Lisboa, Círculo de Leitores.

LOURO, Francisco (1976), "Um testamento inédito do rei D. Luís", Bracara Augusta, Braga, vol. $30, \mathrm{n}^{\circ} 69$ (81), pp. 179-183.

LOURO, Francisco (1987), "A Rainha D. Maria Pia” em Rainha D. Maria Pia. Iconografia, Lisboa, Palácio Nacional da Ajuda (sem paginação).

LOURO, Francisco \& PINTO, Graça Mendes, texto e organização do catálogo (1990), D. Luís I duque do Porto e rei de Portugal. Catálogo, Lisboa, Palácio Nacional da Ajuda. 
MACHUQUeIRO, Pedro Urbano da Gama (2005), A casa Palmela e o desafio liberal: estratégias de afirmação, Lisboa, FCSH da Universidade Nova de Lisboa.

Marques, A. H. de Oliveira, coord. (1991), Portugal da Monarquia para a República (vol. XI da Nova História de Portugal dir. por Joel Serrão e Oliveira Marques), Lisboa, Presença.

MARTINS, Francisco da Rocha (1926), D. Carlos. História do seu reinado, s.l., Ed. A.

MARTINS, Francisco da Rocha (1931), D. Manuel II, historia do seu reinado e da implantação da República, s.l., Ed. A.

MAZZONIS, Filippo (2003), La monarchia e il Risorgimento, Bolonha, Il Mulino.

MÓNICA, Maria Filomena, coord. (2004-2006), Dicionário biográfico parlamentar, 1834-1910, Lisboa, ICSUL/Assembleia da República.

MONTI, Antonio (1935), Donne e passioni del Risorgimento, Milão, Corticelli.

MONTI, Antonio (1939), La giovinezza di Vittorio Emanuele II (1820-1849), Milão, A. Mondadori

MONTI, Antonio (1941), Vittorio Emanuele II (1820-1878), Milão, Garzanti.

NEMÉSIO, Vitorino (1953), O destino de Gomes Leal. Seguido de poesias escolhidas (com dispersos desconhecidos), Lisboa, Bertrand.

NOBRE, Eduardo $\left(2003^{a}\right)$, Casa Real. Fotografias, Documentos, Manuscritos, Memorabilia, s.l., Quimera.

NOBRE, Eduardo (2003b), Família Real. Álbum de fotografias, s.l., Quimera.

NOBRE, Eduardo (2005'b), Paixões Reais, s.l., Quimera.

NOBRE, Eduardo (2006), Amélia, rainha de Portugal, s.l., Quimera.

NOBRE, Eduardo (2008), O trono e as lágrimas. 10 histórias de princesas que não foram felizes para sempre, Lisboa, Quimera.

Noronha, Eduardo de (1912), o passado. Reminiscências anedoticas dos tempos idos, Porto, Magalhães \& Moniz.

Noronha, Eduardo de (1926), Fontes Pereira de Melo e os seus colaboradores. Complemento do livro A Regeneração. Mais subsídios para a história política portuguesa no século XIX, Porto, Companhia Portuguesa Editora.

NORONHA, Eduardo de (1928), Reinado florescente, soberano pacífico. Alguns elementos para a reconstituição da época de D. Luiz I, Lisboa, João Romano Torres.

NORONHA, Eduardo de (s.d. ${ }^{a}$ ), A Regeneração. Fontes Pereira de Melo e os seus colaboradores. Mais subsídios para a história da sua vida, meio, obra, factos, amores e aventuras. Porto, Companhia Portuguesa Editora.

NORONHA, Eduardo de (s.d. b), O rei marinheiro. Subsidios para a história politica, social, militar, litterária, industrial e artística do reinado de D. Luiz I, Lisboa, João Romano Torres.

OlIVA, Gianni (2009), I Savoia. Novecento anni di una dinastia, s.l., Mondadori.

PAIXÃO, V. Braga (1965), Últimos casamentos na Casa Real em Portugal, Lisboa, Sep. das Memórias da Academia das Ciências de Lisboa (Classe de Letras, T VIII).

PAVÃo, José Manuel \& CERQueIRA, João (2007), Maria Pia. Rainha e mulher, Mirandela, João Azevedo Editor.

Pereira, Ana Marques (2000), Mesa Real. Dinastia de Bragança, Lisboa, Inapa.

PEREIRA, Esteves \& RODRIGUes, Guilherme (1904-1915), Portugal. Diccionario historico, chorographico, heraldico, biographico, bibliographico, numismatico e artístico, 7 vols., Lisboa, João Romano Torres. 
PESCI, Ugo (1904), Firenze capitale (1865-1870). Dagli appunti di un ex cronista, Florença, Bemporad.

PINTO, Albano da Silveira \& BAENA, Visconde Sanches de (1991), Resenha das Familias Titulares e Grandes de Portugal, Braga, s.n.

Porto 1865, uma exposição, Lisboa, Expo-98, 1994.

ProençA, Maria Cândida (2006), D. Manuel II, Lisboa, Círculo de Leitores.

QueIRÓs, Francisco Fortunato (2003), A questão ibérica. Correspondência de D. Fernando, marquês de Sá da Bandeira, conde de Alte e duque de Saldanha, Portalegre, Instituto Politécnico de Portalegre.

Rainha D. Maria Pia. Iconografia, Lisboa, Palácio Nacional da Ajuda, 1987.

RAMALHO, Margarida de Magalhães (2003), Uma corte à beira-mar: 1870-1910, Lisboa, Quetzal.

RAMOs, Rui (1994), A segunda fundação (1890-1826), vol. VI da História de Portugal dir. por José Mattoso, Lisboa, Círculo de Leitores.

RAmos, Rui (2001), "D. Amélia, a grande", Análise Social, Lisboa, vol. 36, n 160, pp. 915-924.

Ramos, Rui (2006), D. Carlos, Lisboa, Círculo de Leitores.

Rebelo, Teresa (2006), Condessa d'Edla. A cantora de ópera quasi rainha de Portugal e de Espanha (1836-1929), Lisboa, Alêtheia Editores.

Rei D. Luís I. Iconografia, Lisboa, Palácio Nacional da Ajuda, 1990.

RIBEIRO, Victor (1901-07), "Historia da beneficencia publica em Portugal", O Instituto, Coimbra, vols. 48 a 54 (em 1907 editada em livro pela Imprensa da Universidade de Coimbra).

ROMANONES, conde de (1965), Amadeo de Saboya, El-Rey Efímero. España y los orígenes de la guerra francoprusiana de 1870, Madrid, Espasa-Calpe.

Rossi, G. G. (1941), "Maria Pia di Savoia nei poeti portoghesi” em Italia e Portogallo, Florença, Vallecchi Editore, pp. 59-93.

SÁ, Aires de (1928), Rainha D. Amélia, Lisboa, Parceria Antonio Maria Pereira.

SÁ, Aires de (1929), Principe Real D. Luiz Filipe, Lisboa, Parceria Antonio Maria Pereira.

SÁ, Isabel dos Guimarães \& LOPES, Maria Antónia (2008), História breve das Misericórdias portuguesas, Coimbra, Imprensa da Universidade.

SABugosa, conde de (1912), Neves de antanho, Lisboa, Portugal-Brasil Sociedade Editora.

SAMPAYO, Luiz Teixeira de (1984), Estudos históricos, Lisboa, Ministério dos Negócios Estrangeiros.

SANTOS, Eduardo dos (1986), A questão do Barotze, Lisboa, Instituto de Investigação Científica Tropical.

SEQueIRA, Gustavo de Matos (1961), o Palácio Nacional da Ajuda. Resenha histórica, Lisboa, s.n.

SILVA, César da (1922), A derrocada de um trono. Crónica dos dois últimos reinados em Portugal, 1889-1910, Lisboa, João Romano Torres.

Silveira, Luís Espinha da \& FERnANDES, Paulo Jorge (2006), D. Luís, Lisboa, Círculo de Leitores.

SMITH, Denis Mack (1971), Victor Emanuel, Cavour and the Risorgimento, Londres, Oxford University Press.

SMITH, Denis Mack (2008), I Savoia re d'Italia, s.l., BUR.

SOUSA, Fernando de \& MARQues, A. H. de Oliveira, coord. (2004), Portugal e a Regeneração (vol. X da Nova História de Portugal dir. por Joel Serrão e Oliveira Marques), Lisboa, Presença.

TeIXeIra, José (1986), D. Fernando II. Rei-artista, artista-rei, Lisboa, Fundação da Casa de Bragança. 
TINOP (1938), Lisboa de outrora, $1^{\circ}$ vol., Lisboa, Grupo "Amigos de Lisboa".

TINOP (1939), Lisboa de outrora, $3^{\circ}$ vol., Lisboa, Grupo "Amigos de Lisboa".

Tricolore (http://www.tricolore-italia.com/pdf/spec/). Consultado a 4.2.2009.

VAQUINHAS, Irene (2000), "Senhoras e Mulheres" na sociedade portuguesa do século XIX, Lisboa, Colibri.

VAsconcelos, Francisco de (2003), A nobreza do século XIX em Portugal, Porto, Centro de Estudos de Genealogia.

ZAGAlo, Manuel C. de Almeida Caiola (1961), O Palácio Nacional da Ajuda. Resenha histórica, Lisboa, s.n.

ZÚQueTE, Afonso Duarte Martins, dir. (1989), Nobreza de Portugal e do Brasil, 3 vols., Lisboa, Editorial Enciclopédia. 